\title{
MODEL CELOVITE OBRAVNAVE FUNKCIONALNO DEGRADIRANIH OBMOČIJ KOT PODPORA TRAJNOSTNEMU PROSTORSKEMU IN RAZVOJNEMU NAČRTOVANJU V SLOVENIJI
}

\author{
dr. Barbara Lampič*, dr. Simon Kušar*, \\ dr. Alma Zavodnik Lamovšek** \\ *Oddelek za geografijo, Filozofska fakulteta Univerze v Ljubljani, \\ Aškerčeva 2, SI- 1000 Ljubljana \\ **Katedra za prostorsko planiranje, Fakulteta za gradbeništvo in geodezijo \\ Univerze v Ljubljani, Jamova 2, SI- 1000 Ljubljana \\ e-pošta: barbara.lampic@ff.uni-lj.si, simon.kusar@ff.uni-lj.si, alma.zavodnik@fgg.uni-lj.si
}

Izvirni znanstveni članek

COBISS 1.01

DOI: 10.4312/dela.48.2.5-59

\section{Izvleček}

V prispevku predstavljamo značilnosti funkcionalno degradiranih območij (FDO) v Sloveniji, kriterije za njihovo opredelitev, tipologijo ter argumente za nadaljnje spremljanje in redno ažuriranje novega prostorskega in podatkovnega sloja. Natančna prostorska umeščenost in poznavanje značilnosti razvrednotenih območij predstavljata pomemben korak v smeri trajnostnega načrtovanja in umeščanja dejavnosti v prostor. Leta 2017 smo v Sloveniji evidentirali 1081 FDO v skupni površini 3423 ha, med katerimi prevladujejo območja industrijskih in obrtnih dejavnosti.

Ključne besede: funkcionalno degradirano območje (FDO), evidenca, kriteriji za opredelitev, tipologija, spremljanje, prostorsko načrtovanje, trajnostni razvoj

\section{UVOD}

Hitre družbene in gospodarske spremembe močno vplivajo tudi na vse hitrejšo dinamiko prostorskega razvoja. Na eni strani se srečujemo z vse večjimi zahtevami investitorjev po novih območjih za razvoj dejavnosti, na drugi z vedno večjo dinamiko opuščanja že vzpostavljenih dejavnosti, kar vodi v različne vrste degradacije, najpogosteje pa v fizično degradacijo prostora.

Degradirano območje je najpogosteje opredeljeno kot območje, ki je prizadeto zaradi pretekle rabe oziroma človekove dejavnosti, je opuščeno ali premalo izkoriščeno in 
pogosto tudi onesnaženo (Alker in sod., 2000; Bergatt Jackson in sod., 2006; Špes in sod., 2012). Če na eni strani degradiranost prostora predstavlja določeno (na primer okoljsko, finančno) breme, pa so lahko tovrstna območja, ob pomanjkanju nepozidanih površin, bistvena za zagotavljanje nadaljnjega razvoja predvsem v gosto poseljenih urbanih območjih (Špes in sod., 2012). Umeščanje dejavnosti v predhodno že uporabljen prostor zmanjšuje tudi pritisk širitve dejavnosti na kmetijska in gozdna zemljišča (t. i. greenfield razvoj), kar je pomemben prispevek k doseganju ciljev trajnostnega prostorskega razvoja (Lampič in sod., 2016; Lampič in sod., 2017a), ničelne neto pozidave (Science for Environment Policy, 2016) ter racionalne rabe prostora.

Dosedanja prizadevanja v Sloveniji, da se prične reševati problematiko različnih oblik degradacije v prostoru, so bila neuspešna, saj ni bilo celovitega pristopa niti k razumevanju pojava niti k njegovi opredelitvi oziroma definiciji. Posledično je bilo degradirana območja težko prepoznati in ustrezno prostorsko zamejiti, vzpostaviti kakovostne prostorske in podatkovne baze ter pojav degradacije prostora ustrezno spremljati. Dosedanji pristopi zato niso omogočali aktiviranja prostorsko-razvojnega potenciala številnih degradiranih območij v Sloveniji, ki so bila posledica strukturnih sprememb v gospodarstvu. Proces njihovega nastajanja se je pospešil po letu 2010, ko so se vplivi svetovne finančno-gospodarske krize pričeli jasneje kazati tudi v slovenskem prostoru: nadaljevalo se je postopno zapiranje različnih gospodarskih podjetij, istočasno pa so ostajale nedokončane številne druge razvojne pobude (gradnje novih stanovanjskih sosesk, novih poslovnih con idr.). Nove investicije so se v postkriznih časih v veliki meri usmerjale predvsem na še ne pozidana kmetijska in gozdna zemljišča. Ocenjena izguba zemljišč v obdobju od leta 1992 do 2017 je okoli 45.000 ha, kar pomeni, da smo v zadnjih 25 letih na dan v Sloveniji v povprečju izgubili 5 ha kmetijskih oziroma gozdnih zemljišč (Grčman, 2017). Za nadaljnjo preprečitev tovrstnih procesov in za jasnejše uresničevanje načel trajnostnih usmeritev pri umeščanju novih dejavnosti v prostor je treba, poleg oblikovanja ustreznih prostorskih in podatkovnih evidenc o obstoječih degradiranih območjih v Sloveniji, aktivirati razpoložljivo znanje na področju prostorskega in razvojnega načrtovanja ter vzpostaviti delujoče mehanizme prednostnega umeščanja dejavnosti na funkcionalno neizkoriščen in razvrednoten prostor.

Ključen pogoj za ustrezno obravnavo problematike degradiranih območij v Sloveniji je identifikacija degradiranih območij - prepoznavanje in evidentiranje njihovega števila, površine in drugih geografskih značilnosti. Namen prispevka je z opredelitvijo modela za celovito obravnavo funkcionalno degradiranih območij, ki jih razumemo kot nezadostno izkoriščena ali zapuščena območja z vidnim vplivom predhodne rabe, preseči teoretične in metodološke vrzeli pri njihovi obravnavi v Sloveniji. Cilji prispevka so zato: (1) podrobneje predstaviti metode za ustrezno prepoznavanje in evidentiranje funkcionalno degradiranih območij (v nadaljevanju FDO), (2) na osnovi obsežnih podatkov, pridobljenih z evidentiranjem FDO v Sloveniji v letih 2016 in 2017, opredeliti njihove temeljne geografske značilnosti ter (3) na osnovi izkušenj z obravnavo FDO podati usmeritve na področju njihove obravnave, ki bodo prispevale k učinkovitejšemu prostorskemu in razvojnemu načrtovanju v Sloveniji. S teoretičnimi, metodološkimi in praktičnimi izkušnjami iz raziskave želimo prispevati k razvoju mehanizmov in ukrepov, 
ki bodo zagotavljali minimalen obseg nastajanja novih FDO ob razmeroma uspešnem oživljanju obstoječih.

Prispevek vsebinsko začenjamo z analizo literature in drugih virov, ki vključuje teoretične in metodološke vidike obravnave degradiranih območij in njihove tipologije. Rezultat te analize je med drugim opredelitev pojma (funkcionalno) degradiranih območij. Prav tako smo z najnovejšimi spoznanji na obravnavanem področju lahko podprli tudi ostale faze opravljene raziskave, ki sledijo v nadaljevanju prispevka: metoda določitve FDO (tipologija in kriteriji za zajem), analiza rezultatov popisa FDO v Sloveniji, vrednotenje trenutnih razvojnih možnosti FDO ter kritična ocena dosedanjih praks upravljanja funkcionalno razvrednotenega prostora.

\section{DOSEDANJE IZKUŠNJE Z OBRAVNAVANJEM DEGRADIRANIH OBMOČIJ}

\section{I Opredelitev (funkcionalno) degradiranih območij}

Obravnava degradiranih območij je vsebinsko povezana predvsem s proučevanjem in vrednotenjem prostorskih razsežnosti strukturnih sprememb v gospodarstvu, vključno s kmetijstvom, pa tudi v stanovanjski gradnji in drugih dejavnostih. Spremembe se kažejo v nastanku opuščenih ali delno opuščenih območij oziroma območij, ki niso več v rabi, ker so se dejavnosti na njih prenehale izvajati. Kljub razmeroma številnim poskusom obravnave tega prostorskega pojava v posameznih državah in na znanstvenoraziskovalnem področju, razumevanje in obravnava degradiranih območij nista poenotena (Lampič in sod., 2016; Lampič in sod., 2017a). Degradirana območja so v različnih državah vsebinsko zelo raznoliko opredeljena, v svetovnem merilu pa se nobena organizacija ali iniciativa ne ukvarja z zbiranjem metodološko primerljivih podatkov o tipih, številu, površini ali možnostih sanacije degradiranih območij (Špes in sod., 2012). Opredelitev degradiranih območij je praviloma tesno povezana $\mathrm{z}$ namenom in cilji raziskovalno-razvojnih pristopov, problematika pa je največkrat prepuščena urejanju na regionalni in/ali državni ravni.

Iz analize opredelitve pojma degradirano območje po posameznih državah (Bergatt Jackson in sod., 2006; Encyclopedic Dictionary of Landscape and Urban Planning, 2010; Špes in sod., 2012; Lipovac, 2014; Klančišar Schneider, 2014 idr.) je razvidno, da se degradirana območja povezuje predvsem z onesnaženostjo in zmanjšano kakovostjo okolja. Tako so v Španiji degradirana območja nekdanja industrijska območja, ki so onesnažena (ali obstaja sum na onesnaženost) in se nahajajo na urbanih ali suburbanih območjih. Podobno velja za Kanado (Dasgupta, Tam, 2009) in Združene države Amerike (Encyclopedic Dictionary of Landscape and Urban Planning, 2010), kjer kot degradirana območja obravnavajo nepremičnine, katerih širjenje, ponovna raba ali prenova je ovirana zaradi potencialne ali dejanske onesnaženosti z nevarnimi snovmi oziroma onesnažili. Dasgupta in Tam (2009) še navajata, da so v Kanadi degradirana območja definirana kot opuščena, neizrabljena ali le delno uporabljena trgovska/komercialna 
ali industrijska posest, na kateri so pretekle aktivnosti povzročile onesnaženost (ali obstaja sum nanjo) in kjer je prisoten potencial za ponovni razvoj. Velika Britanija se uvršča med države z najbolj sistematično obravnavo degradiranih območij. Osnova za njihovo obravnavo je ažurna baza podatkov o degradiranih območjih (NLUD-PDL, 2004), pripravljen pa je bil tudi poseben priročnik (The Brownfield Guide), ki naslavlja problematiko prenove degradiranih območij (Bergatt Jackson in sod., 2006).

Problematika degradiranih območij je bila obravnavana tudi v okviru mednarodnih raziskovalnih projektov in iniciativ (CLARINET - Ferber, Grimski, 2002; RESCUE, 2002; CABERNET, 2006; COBRAMAN, 2009; DIGISOIL, 2011; TIMBRE, 2011; RETINA, 2012 idr.). V literaturi sta največkrat navedena projekta CABERNET in CLARINET. V okviru projekta CABERNET (2006) so degradirana območja opredelili kot tista, ki so prizadeta zaradi pretekle rabe ali rabe sosednjih območij, so opuščena ali premalo izkoriščena območja, imajo lahko resne probleme $\mathrm{z}$ onesnaženjem (kontaminacijo) in se običajno nahajajo v urbanem okolju. Podobno je degradirana območja obravnaval že projekt CLARINET (Ferber, Grimski, 2002). V projektu RESCUE so oblikovali trajnostno naravnano definicijo, ki degradirana območja opiše z vidika upravljanja, rehabilitacije in vrnitve $\mathrm{v}$ uporabno stanje tako, da se pri tem zagotovi zadovoljevanje človekovih potreb za sedanje in prihodnje generacije z upoštevanjem okoljske občutljivosti (Vojvodíková, Potužník, Bürgermeisterová, 2011). V okviru projekta RETINA (2012) so opredelili degradirano območje kot zapuščeno ali premalo izkoriščeno industrijsko območje, ki se je izoblikovalo po procesu regionalnega ekonomskega prestrukturiranja, kjer bi bila razširitev, ponovna raba ali revitalizacija močno otežena. Projekt COBRAMAN opredeljuje degradirana območja kot (1) prizadeta zaradi preteklega izrabljanja, (2) zanemarjena ali premalo izkoriščena in (3) ležeča predvsem na urbanih območjih in potrebna posega za ponovno koristno uporabo (Klančišar Schneider, 2014).

V zadnjem desetletju je bilo tudi v Sloveniji izvedenih več projektov in raziskav, ki so se ukvarjali z opredelitvijo pojma, izbranimi tipi degradacije ali so se osredotočili na določena degradirana območja. Koželj (1998) je obravnaval kriterije in različne tipe degradiranih urbanih območij, prvi večji sistematični popis izbranih tipov degradiranih območij v Sloveniji pa je bil opravljen v okviru širšega projekta o sonaravni sanaciji okoljskih bremen v Sloveniji. V tem projektu je bil na nacionalni ravni prvič kvantificiran pojav degradiranih območij v skupnem obsegu 979 ha (Špes in sod., 2012). Novejša raziskovalna prizadevanja na področju degradiranih območij so se usmerjala na obravnavo degradiranih območij na urbanih območjih (Koželj in sod., 2016) oziroma so naslavljala regionalno specifično problematiko degradiranih območij (Lampič in sod., 2015; diplomska in magistrska dela, na primer: Hribernik, 2012; Dolinšek, 2016; Zupan, 2016; Udovič, 2017). V letu 2017 pa je bil zaključen prvi sistematičen popis in oblikovana evidenca degradiranih območij, ki celovito prikazuje in z vidika možnosti ponovne oživitve vrednoti funkcionalno izpraznjen oziroma razvrednoten prostor Slovenije (Lampič in sod., 2017a).

Degradirana območja so v Sloveniji opredeljena tudi v strateških dokumentih in zakonodaji, predvsem na področju urejanja prostora (Politika urejanja prostora, 2001; 
Strategija prostorskega razvoja Slovenije, 2004) in varstva okolja (Zakon o varstvu okolja, 2004), kjer so opredeljena kot neizkoriščen prostor, ki predstavlja potencial za notranji prostorski razvoj naselij. Novi Zakon o urejanju prostora (Zakon o urejanju prostora, 2017) ne govori o degradiranih območjih, ampak o razvrednotenih območjih, ki imajo zaradi neprimerne ali opuščene rabe znižano gospodarsko, socialno, okoljsko in/ali vizualno vrednost in so potrebna prenove. Zakon o varstvu okolja (2004) degradirana območja naslavlja skozi obremenjenost okolja.

$\mathrm{V}$ večini analiziranih raziskav in virov so degradirana območja opredeljena kot opuščena ali delno opuščena območja oziroma območja, ki niso več v rabi in kjer so se dejavnosti prenehale izvajati. Degradirana območja se sicer pogosteje pojavljajo na urbanih oziroma urbaniziranih območjih, ne pa izključno le tam. Skupne lastnosti različnih opredelitev degradiranih območij so naslednje:

- viden vpliv predhodne rabe območja,

- zapuščenost in zanemarjenost,

- nezadostna izkoriščenost območja,

- onesnaženost,

- zmanjšana vrednost (prostora in objektov),

- različno izražen potencial za razvoj in

- potreba po sanaciji in revitalizaciji (oživitvi).

Pomembna zadrega pri obravnavi degradiranih območij v Sloveniji izhaja iz terminologije. Slovenski jezik namreč pozna le en pojem degradiranega območja, ki pa se lahko vsebinsko veže na okoljsko onesnaženost ali pa na katero drugo vrsto degradacije, kot je socialna ali vizualna degradacija. Ocenjujemo, da od tod izvira največ težav pri opredeljevanju pojma degradirano območje, saj je nemogoče postaviti eno samo definicijo pojma, ki bi lahko upoštevala vse vsebinske odtenke, ki se nanašajo na degradacijo prostora in okolja. Natančnejša opredelitev pojma degradirano območje zato zahteva, da definicijo spremlja dodatna vsebinska opredelitev s kriteriji za identifikacijo degradiranih območij (kot na primer fizična degradacija prostora, degradacija okolja/okoljskih sestavin, socialna degradacija).

\subsection{Tipologije degradiranih območij}

Osnovne opredelitve degradiranih območij v določeni meri že govorijo o tipih degradiranih območij (na primer Dasgupta, Tam, 2009; Lipovac, 2014), za njihov podrobnejši opis pa so bile oblikovane različne tipologije. Tipologija degradiranih območij tako opisuje njihove temeljne lastnosti ter omogoča njihovo sistematično obravnavo in lažjo identifikacijo (Adams, De Sousa, Tiesdell, 2010).

Med funkcionalno degradirana območja v literaturi (preglednica 1) najpogosteje prištevajo nekdanja industrijska območja oziroma zapuščene tovarne v industrijskih conah v mestih (Encyclopedic Dictionary of Landscape and Urban Planning, 2010). Mednje prištevajo tudi opuščena skladišča in zaprte trgovske objekte (Brownfield Action, 2015; Landscapes2 ..., 2015; Lange, McNeil, 2004). Martinec (2006; cv: Vojvodíková, 
Potužník, Bürgermeisterová, 2011) opredeljuje 5 tipov degradiranih območij: poleg industrijskih še rudarska, kmetijska, vojaška in t. i. socialna območja. Prostorska in podatkovna zbirka degradiranih območij v Češki republiki deli degradirana območja glede na preteklo rabo na naslednje tipe: stanovanjska območja, območja za turizem, območja prometa, industrijska, rudarska, kmetijska in vojaška območja, območja javnih storitev in drugo (Vojvodíková, Potužník, Bürgermeisterová, 2011). Podobno tipologijo, a z nekaj posebnosti, so pripravili tudi Bergatt Jackson in sodelavci (2006). Industrijskim, infrastrukturnim (še posebej območjem železnice) in poslovno-trgovskim območjem dodajajo še naslednje tipe: kmetijska (ostanki kolektivnega kmetijstva), institucionalna (območja javnih storitev, kot so šole, zapori, bolnišnice), kulturna (območja kulturne dediščine, kinodvorane) ter športna in prostočasna degradirana območja. Na prisotnost slednjega tipa opozarja tudi Gauchon (1997), ki opozarja na opuščena območja žičnic. Podobno tipologijo uporablja tudi projekt COBRAMAN (COBRAMAN Brownfield Types, 2016), ki opredeljuje 6 tipov degradiranih območij: industrijska, vojaška, rudarska in železniška degradirana območja oziroma lokacije, dodaja pa tudi obvodne lokacije (waterfront) in območja mestoslužnih (centralnih) dejavnosti.

Tudi v slovenski literaturi je mogoče identificirati različne tipologije degradiranih območij. V prvi sistematični obravnavi degradiranih urbanih območij v slovenskih mestih je Koželj (1998) opredelil 7 osnovnih tipov: industrijska in pristaniška območja ter območja železnice, rudarska območja, vojaška območja, sive cone, stanovanjska območja, predmestja ter staromestna jedra. Kasneje so Špes in sodelavci (2012) pri vzpostavitvi prve celovite evidence degradiranih območij v Sloveniji izhajali iz štirih ključnih tipov (industrijska, rudarska, infrastrukturna in vojaška degradirana območja), v praksi pa je raziskava na terenu potrdila potrebo po razširitvi nabora, ki je bila kasneje izvedena v okviru raziskave o funkcionalno degradiranih območjih v Gorenjski statistični regiji (Lampič in sod., 2015). Za njihovo evidentiranje so avtorji oblikovali tipologijo z 11 tipi funkcionalno degradiranih območij. Industrijskim, rudarskim, infrastrukturnim in vojaškim degradiranim območjem so se pridružili še turistična in rekreacijska FDO, FDO kulturne dediščine, kmetijska FDO, poslovno-trgovska FDO, stanovanjska FDO, stara vaška jedra ter odlagališča. Tipologija nadgrajuje pristop iz leta 2012 (Špes in sod., 2012) ter poudarja specifične prostorske izzive Gorenjske statistične regije. V letu 2017 je bil oblikovan dopolnjen sistem za evidentiranje FDO ter testiran v pilotnih statističnih regijah (Lampič in sod., 2017b).

Izkušnje Koželja (1998) z obravnavo degradiranih urbanih območij in raziskave Špesove s sodelavci (2012) so bile nadgrajene tudi leta 2016, ko so bila v urbanih delih mestnih občin v Sloveniji popisana nerevitalizirana urbana območja (NERUO). NERUO v mestnih občinah so bila združena v 10 tipov. Njihova opredelitev se je naslanjala na namensko rabo zemljišč: območja stanovanj, območja centralnih dejavnosti, območja proizvodnih dejavnosti, območja za turizem in rekreacijo, območja zelenih površin, območja infrastrukture, območja za potrebe obrambe in varstva pred naravnimi in drugimi nesrečami, območja kmetijske proizvodnje, območja pridobivanja mineralnih surovin ter območja prehodno pasivne rabe (Koželj in sod., 2016). 
Preglednica 1: Oris najpogosteje opredeljenih tipov degradiranih območij.

\begin{tabular}{|l|l|}
\hline Tip degradiranega območja & Značilni primeri \\
\hline Industrijska & zapuščene tovarne \\
\hline Poslovno-trgovska & zaprti trgovski objekti \\
\hline Rudarska & opuščena rudarska območja in zaradi rudarstva prizadeta območja \\
\hline Kmetijska & ostanki kolektivnega kmetijstva \\
\hline Vojaška & vojašnice, karavle, vojaški poligoni \\
\hline Stanovanjska & predmestja \\
\hline Prometna & območja opuščenih železnic, pristanišč, skladišč, mejnih prehodov \\
\hline Javnih storitev & opuščene šole, zapori, bolnišnice \\
\hline Kulture & propadajoča kulturna dediščina, opuščene kinodvorane \\
\hline Turistična, športna in prostočasna & opuščena območja žičniških naprav \\
\hline Sive cone & neizkoriščena območja \\
\hline Mestna središča & opuščanje storitvenih dejavnosti v mestnih središčih \\
\hline
\end{tabular}

Vir podatkov: Gauchon, 1997; Koželj, 1998; Lange, McNeil, 2004; Bergatt Jackson, 2006; Martinec, 2006, cv: Vojvodiková, Potužník, Bürgermeisterová, 2011; Encyclopedic Dictionary of Landscape and Urban Planning, 2010; Vojvodíková, Potužnik, Bürgermeisterová, 2011; Brownfield Action, 2015; Lampič in sod., 2015; Landscapes2 ..., 2015; COBRAMAN Brownfield Types, 2016; Koželj in sod., 2016.

Večina tipologij degradiranih območij temelji torej na predhodni rabi zemljišč. Izkušnje z obravnavo degradiranih območij kažejo, da je raba zemljišč zelo pestra, saj se neprestano spreminja in prilagaja družbenim potrebam. Zato je za potrebe podrobnejše proučitve degradiranih območij in za potrebe primerjalne časovne analize posamezen tip degradiranih območij lahko razdeljen na podtipe, ki natančneje opredeljujejo nastanek degradacije (Vojvodíková, Potužník, Bürgermeisterová, 2011). Takšen pristop je bil že upoštevan in uporabljen pri raziskavi o funkcionalno degradiranih območjih v Gorenjski statistični regiji (Lampič in sod., 2015).

\section{METODA EVIDENTIRANJA IN SPREMLJANJA FUNKCIO- NALNO DEGRADIRANIH OBMOČIJV SLOVENIJI}

Pri opredelitvi degradiranih območij za potrebe predstavljene raziskave smo upoštevali predvsem funkcionalno razvrednotenje prostora, ki pogosto predstavlja potencial za nadaljnji prostorski razvoj. Opredelitev degradiranih območij smo torej nekoliko zožili in se opredelili le do funkcionalno degradiranih območij. V predlagano opredelitev pojma vključujemo degradirana območja tako v urbanem kot odprtem prostoru, kar je ključno za kasnejšo uporabo v predlaganem celovitem sistemu spremljanja (funkcionalno) degradiranih območij v Sloveniji.

FDO smo opredelili kot nezadostno izkoriščeno ali zapuščeno območje z vidnim vplivom predhodne rabe in zmanjšano uporabno vrednostjo. To lahko predstavlja potencial za razvoj; FDO pa lahko oživimo s sektorsko usklajenimi predpisi in ukrepi za prenovo. 
Za delovanje celotnega sistema, ki bo omogočal (zagotavljal) prenovo in oživitev FDO, Adams, De Sousa in Tiesdell (2010) prepoznavajo kot bistvene naslednje aktivnosti: identifikacijo FDO (njihova vsebinska opredelitev - tipologija, opredelitev kriterijev za zajem, vzpostavitev baze v obliki evidence ali registra), prepoznavanje potencialov in nevarnosti FDO (analiza razmer), (okoljska) sanacija, priprava vizije celovite prenove FDO, načrtovanje prenove FDO, izdelava izvedbenega načrta, izvajanje načrta, spremljanje izvajanja sprejetih načrtov in zasledovanje ciljev.

Praviloma je prvi korak, to je evidentiranje FDO, že sistemsko vzpostavljena aktivnost na ravni države v okviru sistemskega spremljanja stanja in procesov v prostoru. To pa za Slovenijo ne drži, saj celovite evidence na ravni države do predstavljene raziskave ni bilo. V Sloveniji smo tako v okviru celovitega pristopa k obravnavi FDO prvič zasnovali in vzpostavili osnovni sistem za evidentiranje in spremljanje FDO, ki vključuje:

1. oblikovanje tipologije FDO, ki opisuje temeljne lastnosti posameznega FDO glede na predhodno dejavnost in omogoča nadaljnjo sistematično obravnavo FDO;

2. opredelitev kriterijev FDO, ki omogočajo določitev relevantnih območij (v prostoru);

3. postopek identificiranja in evidentiranja FDO, ki zagotavlja pridobivanje podatkov na terenu s terenskim ogledom, popisom ter intervjuji z deležniki na lokalni (občinski) ravni;

4. vzpostavitev in vzdrževanje evidence FDO, ki vključuje vnos identifikacijskih, vsebinskih in prostorskih podatkov v spletno aplikacijo skupaj s fotografijami, aplikacija pa omogoča pregled in osnovne analize FDO ter možnost dopolnjevanja evidence (spreminjanje podatkov o posameznem FDO, dopolnjevanje evidence z novimi FDO itd.).

\section{I Opredelitev tipov funkcionalno degradiranih območij}

Pri opredelitvi tipov FDO smo izhajali iz predhodne dejavnosti (zadnja dejavnost pred opustitvijo) in Pravilnika o vsebini, obliki in načinu priprave občinskega prostorskega načrta (Pravilnik ..., 2004), na osnovi katerega smo uskladili terminologijo oziroma poimenovanje posameznih tipov FDO. Določili smo 9 osnovnih tipov FDO (preglednica 2). Petim tipom smo določili tudi podtipe, s čimer smo želeli podrobneje opredeliti posamezno obliko FDO (skupaj 15 podtipov FDO). Podtipe FDO smo opredelili pri FDO storitvenih dejavnosti (3 podtipi), FDO pridobivanja mineralnih surovin (4 podtipi), FDO infrastrukture ( 4 podtipi), FDO prehodne rabe ( 2 podtipa) in FDO za bivanje ( 2 podtipa). 
Preglednica 2: Tipologija funkcionalno degradiranih območij.

\begin{tabular}{|c|c|c|}
\hline Id & Tip FDO & Podtip FDO \\
\hline 1 & FDO kmetijske dejavnosti & \\
\hline 2 & FDO storitvenih dejavnosti & $\begin{array}{l}\text { 2.1 FDO javnih storitev } \\
\text { 2.2 FDO poslovnih, trgovskih in drugih storitvenih dejavnosti } \\
\text { 2.3 FDO starega mestnega ali vaškega jedra }\end{array}$ \\
\hline 3 & $\begin{array}{l}\text { FDO turistične, športnorekreacijske in } \\
\text { športne dejavnosti }\end{array}$ & \\
\hline 4 & FDO industrijskih in obrtnih dejavnosti & \\
\hline 5 & FDO obrambe, zaščite in reševanja & \\
\hline 6 & FDO pridobivanja mineralnih surovin & $\begin{array}{l}\text { 6.1 FDO rudnika } \\
\text { 6.2 FDO kamnoloma, peskokopa } \\
\text { 6.3 FDO gramozne jame } \\
\text { 6.4 FDO ostalih območij pridobivanja mineralnih surovin }\end{array}$ \\
\hline 7 & FDO infrastrukture & $\begin{array}{l}\text { 7.1 FDO prometne infrastrukture } \\
\text { 7.2 FDO okoljske infrastrukture } \\
\text { 7.3 FDO ostale gospodarske javne infrastrukture } \\
\text { 7.4 FDO zelene infrastrukture }\end{array}$ \\
\hline 8 & FDO prehodne rabe & $\begin{array}{l}\text { 8.1 FDO opuščenega gradbišča } \\
\text { 8.2 FDO značilne prehodne rabe }\end{array}$ \\
\hline 9 & FDO za bivanje & $\begin{array}{l}\text { 9.1 FDO za bivanje - nedograjena stanovanjska območja } \\
\text { 9.2 FDO za bivanje - stara dotrajana območja }\end{array}$ \\
\hline
\end{tabular}

Tip oziroma podtip FDO ne pomeni neskladne rabe $\mathrm{z}$ opredeljeno namensko rabo $\mathrm{v}$ občinskem prostorskem načrtu (OPN), ampak navaja zadnjo dejavnost pred opustitvijo oziroma trenutno prevladujočo dejavnost v prostoru. Za opredelitev ustreznega tipa in podtipa FDO oziroma za ustrezno razmejitev med posameznimi dejavnostmi je nujen terenski ogled območja.

Vzpostavljena tipologija FDO je odprt sistem, kar pomeni, da je vanj mogoče vključiti nove tipe oziroma podtipe funkcionalne degradiranosti (območij), pa tudi druge vrste degradacij (na primer okoljska, socialna, vizualna, »načrtovalska« - z vidika urbanističnih usmeritev in normativov ipd.), ki pa morajo izhajati iz enakega metodološkega ogrodja kot obravnava FDO (objektivno merljivi kriteriji za njihovo določitev, sistem tipov in podtipov degradiranih območij). 
Slika 1: Tovarna pohištva Novoles v Brežicah je 3,2 ha veliko, od leta 2011 povsem opuščeno industrijsko območje (foto: T. Dokler).

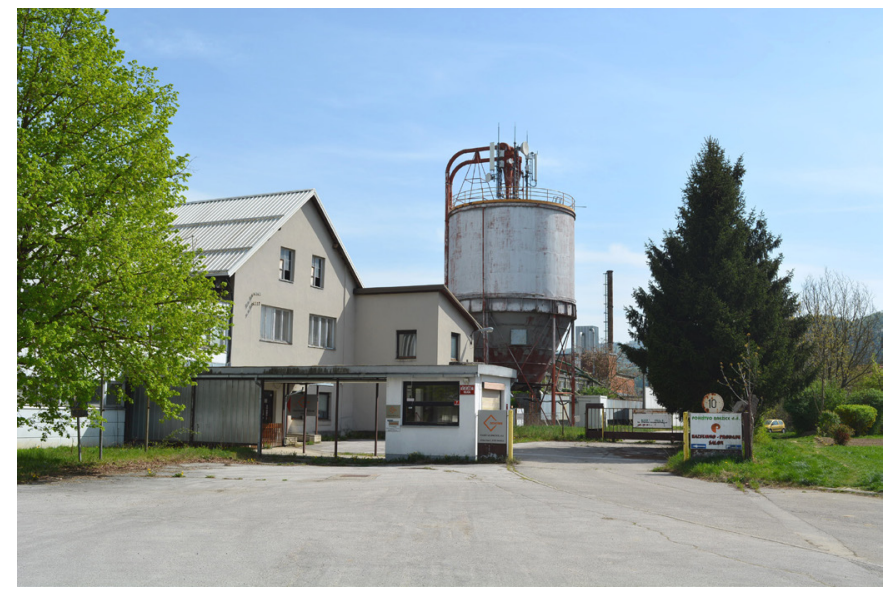

$V$ času obratovanja so emisije Novolesa v zrak predstavljale pomemben okoljski problem. V tujini so degradirana območja pogosto definirana kot opuščena, neizrabljena ali le delno uporabljena območja, na katerih so pretekle dejavnosti povzročale okoljsko onesnaženost.

Slika 2: Poslovna cona Na vrtači v občini Divača (L. Verlič).

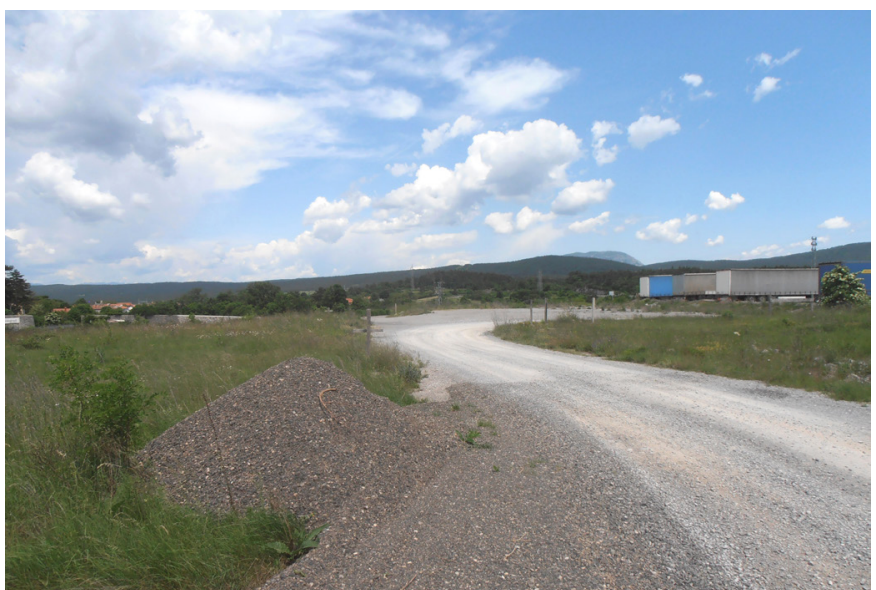

Leta 2005 zgrajena in komunalno opremljena poslovna cona Na vrtači, kljub legi neposredno ob avtocesti, ostaja skoraj povsem nezasedena. Podobno je tudi z nekoliko večjo bližnjo poslovno cono Risnik. Divača je pomembno prometno vozlišče, kar pa ni zadosten lokacijski dejavnik za intenzivnejši razvoj gospodarskih dejavnosti. Nezadostna izkoriščenost prostora je eden večjih izzivov trajnostnega načrtovanja in upravljanja s prostorom. V Sloveniji smo $v$ zadnjem obdobju precej nenačrtno ustanavljali in komunalno opremljali poslovne cone, predvsem na izvozih z novozgrajenih avtocest, ki pa marsikdaj ostajajo prazne ali pa slabo zasedene . 
Slika 3: Nedograjena stanovanjska soseska na robu Divače vključuje 19 stanovanjskih hiš, v letu 2008 zgrajenih do tretje gradbene faze (foto: L. Verlič).

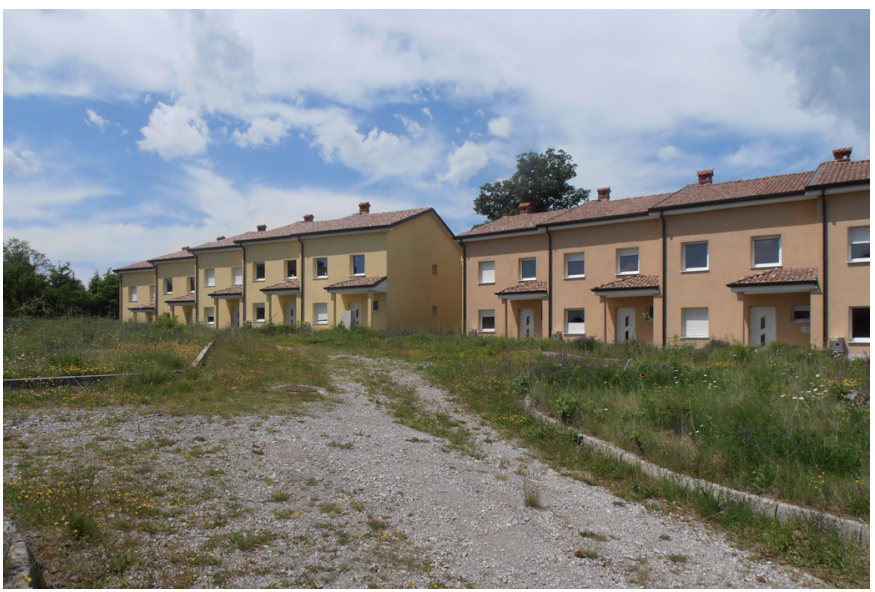

Vsi stanovanjski objekti in pripadajoča zemljišča so opuščeni, z že vidnimi znaki propadanja. Kot v številnih podobnih primerih je investitor v stečajnem postopku, usoda nove, a nikoli žive soseske pa ostaja neznana. Med skupaj 95 popisanimi FDO za bivanje v Sloveniji smo zabeležili tudi 28 nedograjenih stanovanjskih sosesk, ki so bodisi še povsem nenaseljene ali pa je v funkciji le nekaj stanovanj oziroma objektov.

Slika 4: Načrtovana obrtno poslovna cona Dolsko, ki je bila za proizvodno ali gospodarsko cono komunalno opremljena že leta 2011, ostaja povsem neizkoriščeno območje (foto: M. Sevšek).

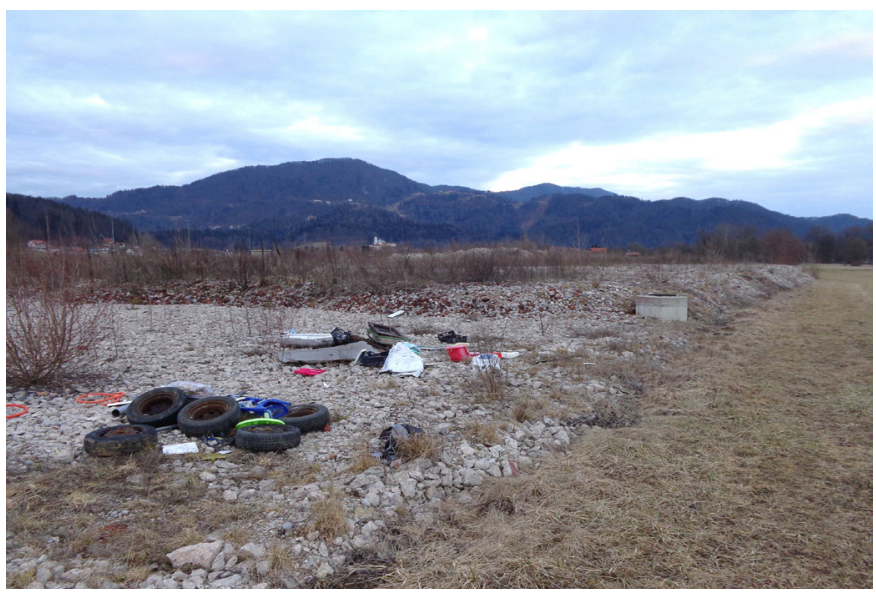

Različne gospodarske dejavnosti so načrtovane na kmetijskih zemljiščih izven naselja Dolsko, sedaj pa je v pripravi nov OPN in sprememba namenske rabe v stanovanjsko območje. Med 112 FDO prehodne rabe je kar 70 območij, kjer je prišlo do opustitve načrtovane investicije (FDO opuščenega gradbišča). Na FDO prehodne rabe se pogosto soočamo tudi s problemi nelegalnega odlaganja odpadkov. 


\subsection{Kriteriji za identificiranje funkcionalno degradiranih območij}

Sistem za spremljanje FDO v ospredje postavlja območja, ki so brez funkcije oziroma se določena funkcija (raba) na območju izvaja v omejenem obsegu. Zato je osnovni kriterij za njihovo opredelitev opuščenost oziroma odsotnost izvajanja dejavnosti. Da smo posamezno obravnavano območje uvrstili med FDO, mora biti vsaj delno opuščeno (vsaj $10 \%$ območja je opuščenega).

Izjema je lahko le v primeru podtipa FDO za bivanje - stara dotrajana območja, ki ga kljub ohranjenosti bivanjske funkcije označujeta izrazita fizična degradacija in poslabšane razmere za bivanje.

FDO morajo izkazovati tudi minimalno velikost. Za kriterij zajema v mestih in mestnih naseljih (upoštevana opredelitev SURS iz leta 2003 - Mestna naselja ..., 2004) smo določili minimalno površino 0,2 ha, ostala območja (odprti prostor) pa morajo obsegati najmanj 0,5 ha. Sistem za zajem relevantnih območij ni tog, ampak se z dovoljenim 20-odstotnim odstopanjem glede velikosti prilagaja raznolikim razmeram v prostoru. Zaradi kriterija minimalne velikosti v nekaterih manjših, pretežno podeželskih občinah (predvsem severovzhodne Slovenije) v evidenco nismo vključili sicer prepoznanih in na terenu evidentiranih FDO (na primer območja opuščenih podružničnih šol, manjših območij storitvenih dejavnosti), ker po površini niso zadostila kriteriju minimalne velikosti.

Slika 5: Osnovna šola Stročja vas v občini Ljutomer je primer FDO javnih storitev, ki je povsem opuščna od leta 2009 (foto: T. Kikec).

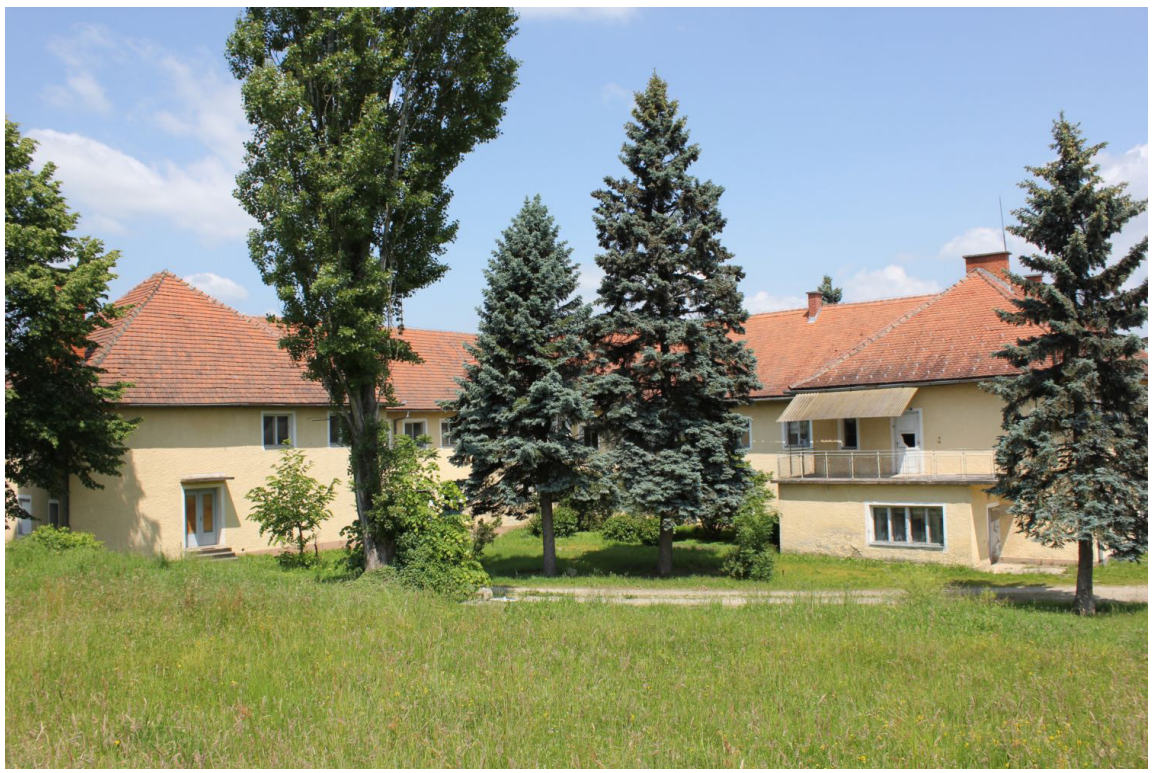

Popisali smo 44 FDO javnih storitev (od skupaj 162 FDO storitvenih dejavnosti), med katerimi so tudi številne opuščene šole. Marsikatere pa-zaradi kriterija minimalne velikosti (0,5 ha) na območjih izven mestnih naselij-s popisom nismo zajeli. 
Slika 6: Šport hotel Areh na Pohorju je eno od številnih FDO turistične, športnorekreacijske in športne dejavnosti v Sloveniji (foto: T. Kikec).

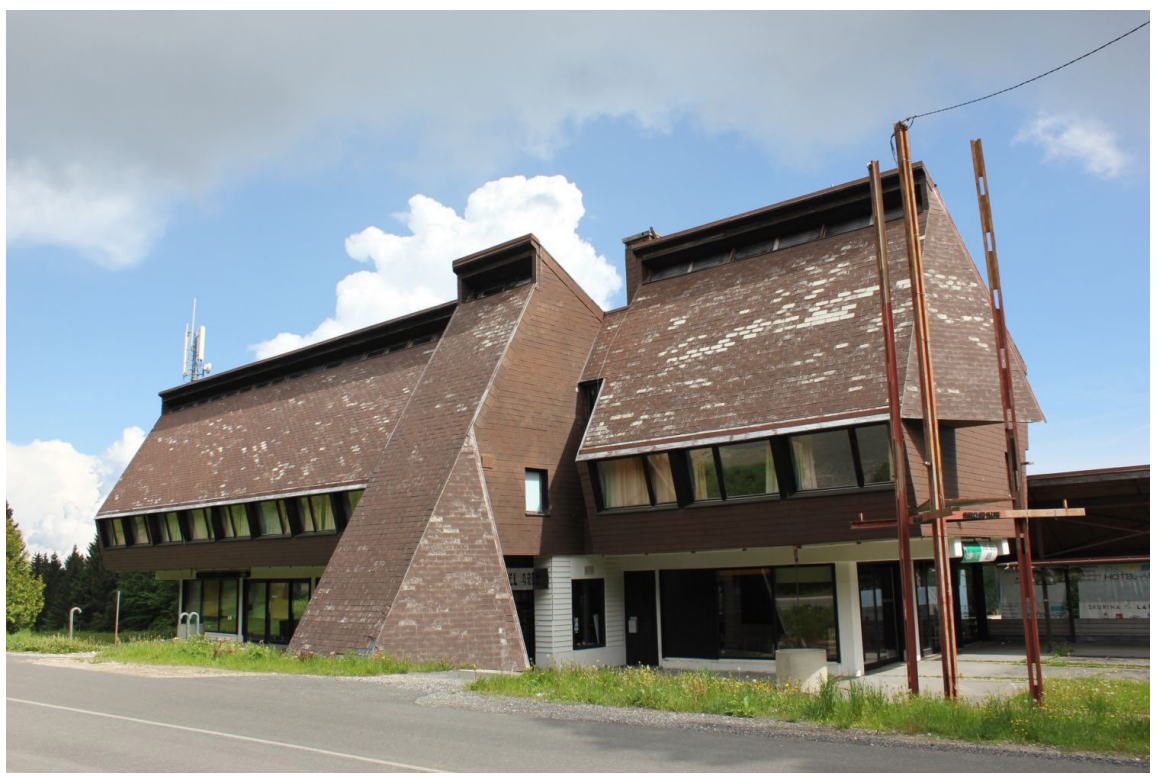

Na območju celotne države smo popisali 60 FDO turistične, športnorekreacijske in športne dejavnosti. Med njimi smo zabeležili večje število opuščenih hotelskih objektov, ki so v veliki večini že pričeli propadati in so v razmeroma slabem stanju. Hotel Areh je konec leta 2017 zamenjal lastnika, po grobih ocenah pa naj bi njegova obnova (strehe, vodovodnih in električnih napeljav, ogrevanja, sob in restavracije) stala vsaj dva milijona evrov.

Osnovnima kriterijema so dodani še dopolnilni kriteriji, ki so namenjeni orisu razmer v FDO, pomembnih tudi za njihovo kasnejše vrednotenje in sprejemanje odločitev glede reaktivacije. Dodatno smo podali še oceno fizične degradacije (vzdrževanost območja) ter sum na socialno (na primer prisotnost vandalizma, nadpovprečna prisotnost kriminala, getoizacija) in okoljsko degradacijo (voda, tal, zraka, vegetacije, površja, drugega). Pri FDO prehodne rabe je upoštevan tudi kriterij časa opuščenosti, kjer se na primer opuščeno gradbišče uvršča med FDO v primeru, da območje gradnje miruje vsaj eno leto.

\subsection{Postopek identificiranja in evidentiranja funkcionalno degradira- nih območij}

Ne glede na številne dostopne prostorske in podatkovne sloje (na primer dejanska raba MKGP, Atlas okolja, aplikacije za prikazovanje statističnih podatkov po prostorskih enotah SURS), ki so v zadnjih letih olajšali in kvalitativno nadgradili obravnave in vrednotenje pojavov v prostoru, za spremljanje pojava FDO ni na voljo ustreznih podlag, ki bi nadomestile dejansko preverjanje stanja na terenu. Ogled območij in situ pogosto ne zadošča, saj zgolj ocena videnega ne odraža vseh dejanskih lastnosti prostora. Terensko delo je zato 
vključevalo tudi intervjuje s pristojnimi za okolje in prostor na občinah, s pomočjo katerih smo pridobili dragocene dodatne kvalitativne podatke (leto opustitve dejavnosti, kronološki pregled razvoja umeščanja dejavnosti, razvojni načrti območja, razvojne ovire, podatki o lastništvu ipd.) o posameznih evidentiranih območjih (preglednica 3).

\section{Preglednica 3: Zbrani podatki o funkcionalno degradiranih območjih v Sloveniji.}

\begin{tabular}{|l|l|}
\hline Podatek o FDO & Metoda pridobitve podatka \\
\hline Tip & ekspertna ocena (na podlagi predhodne dejavnosti in razmer na terenu) \\
\hline Meje & zamejitev na terenu, izris (shp poligoni) \\
\hline Površina & izračun iz prostorskega sloja FDO (shp poligoni) \\
\hline Stopnja opuščenosti & ekspertna ocena na terenu, preverjeno z intervjujem s predstavnikom občine \\
\hline Prisotnost objektov & ekspertna ocena na terenu \\
\hline Stopnja vzdrževanosti & ekspertna ocena na terenu \\
\hline $\begin{array}{l}\text { Lastništvo (javno, } \\
\text { zasebno, mešano) }\end{array}$ & preverjeno z intervjujem s predstavnikom občine, podatki iz zemljiške knjige \\
\hline $\begin{array}{l}\text { Sum na socialno in } \\
\text { okoljsko degradacijo }\end{array}$ & ekspertna ocena na terenu, preverjeno z intervjujem s predstavnikom občine \\
\hline $\begin{array}{l}\text { Razvojni načrti, ovire ter } \\
\text { časovni okvir načrtovanih } \\
\text { aktivnosti za reaktivacijo }\end{array}$ & preverjeno z intervjujem s predstavnikom občine \\
\hline
\end{tabular}

\subsection{Vzpostavitev in vzdrževanje evidence funkcionalno degradiranih območij}

Za namen vzpostavitve nacionalne evidence FDO v Sloveniji je bila izdelana samostojna spletna aplikacija. Izvedena je kot samostojno razvit modul platforme Drupal. Aplikacija služi digitalizaciji evidenčnega popisa, njene funkcionalnosti pa omogočajo vnos podatkov za posamezen FDO, urejanje podatkov posameznega FDO, kartografski prikaz FDO, prenos podatkov popisanih FDO in osnovni analitični prikaz FDO.

Za kartografsko osnovo uporablja Googlove kartografske podlage in omogoča prikazovanje FDO po statističnih regijah in občinah. Prikazujemo lahko vsa FDO, lahko pa prikaze poljubno omejimo po posameznih tipih FDO ali po stopnji opuščenosti (Lampič in sod., 2017a), vendar se bo uporabna vrednost aplikacije in vseh zbranih informacij pokazala ob dejanski uporabi in sprotnem ažuriranju podatkov.

Za zagotavljanje ažurnosti evidence o FDO je nujno vzdrževanje obstoječega podatkovnega in prostorskega sloja. Predlagan sistem za ažuriranje temelji na periodičnem pregledu sprememb na posameznih lokacijah FDO. Na letni ravni je smiselno spremljanje izbranih podatkov o FDO, kot so stopnja zasedenosti/opuščenosti območja, fizično stanje in sprememba površine. $\mathrm{V}$ evidenco pa se dodajajo novonastala FDO oziroma označi izbris FDO zaradi oživitve.

$\mathrm{Na}$ osnovi sprotnega, sicer nesistematičnega spremljanja razvoja že evidentiranih FDO v Sloveniji (predvsem območij, ki smo jih evidentirali v letu 2016) že danes ugotavljamo, da na letni ravni lahko pričakujemo spremembe na 15-20\% evidentiranih lokacij (skupaj z upoštevanimi novonastalimi FDO oziroma oživljenimi FDO). 


\section{REZULTATI IZVEDENEGA ZAJEMA IN ANALIZA FUNK- CIONALNO DEGRADIRANIH OBMOČIJV SLOVENIJI}

Predlagana metoda za celovit zajem in spremljanje pojava FDO je bila za prvo evidentiranje FDO uporabljena in preverjena v letih 2016 in 2017. Terensko delo je potekalo v dveh obdobjih. Prvi del smo izvajali od aprila do septembra 2016 (območje sedmih statističnih regij: Pomurska, Podravska, Posavska, Zasavska, Jugovzhodna Slovenija, Goriška in Gorenjska), drugega pa od aprila do septembra 2017 (območje preostalih petih statističnih regij: Osrednjeslovenska, Primorsko-notranjska, Obalno-kraška, Savinjska in Koroška). V postopku evidentiranja smo prepoznali in v celoti popisali 1081 FDO s skupno površino 3422,7 ha. FDO smo zabeležili v 170 (od 212) slovenskih občinah, v skupaj 35 občinah smo evidentirali po več kot 10 FDO.

Po številu (slika 7) so prevladovala FDO industrijskih in obrtnih dejavnosti (skupaj 237 območij), FDO pridobivanja mineralnih surovin (skupaj 170 območij, od tega 128 kamnolomov) in FDO storitvenih dejavnosti (znotraj tega tipa je bilo največ (84) FDO poslovnih, trgovskih in storitvenih dejavnosti). Po površini so prav tako prevladovala FDO industrijskih in obrtnih dejavnosti (1196,9 ha), FDO pridobivanja mineralnih surovin (649,9 ha) in FDO infrastrukture (418,4 ha). Povprečna velikost FDO znaša 3,2 ha; v povprečju so največja FDO industrijskih in obrtnih dejavnosti $(5,1$ ha), najmanjša pa FDO za bivanje, ki obsegajo le 1,1 ha (preglednica 4).

Preglednica 4: Število, skupna površina in povprečna velikost po tipih funkcionalno degradiranih območij $v$ Sloveniji.

\begin{tabular}{|l|r|c|c|}
\hline Tip FDO & $\begin{array}{c}\text { Število } \\
\text { FDO }\end{array}$ & Površina FDO (ha) & $\begin{array}{c}\text { Povprečna velikost } \\
\text { FDO (ha) }\end{array}$ \\
\hline FDO kmetijske dejavnosti & 77 & 202,3 & 2,6 \\
\hline FDO storitvenih dejavnosti & 162 & 324,3 & 2,0 \\
\hline $\begin{array}{l}\text { FDO turistične, športnorekreacijske in } \\
\text { športne dejavnosti }\end{array}$ & 60 & 102,2 & 1,7 \\
\hline FDO industrijskih in obrtnih dejavnosti & 237 & 1196,9 & 5,1 \\
\hline FDO obrambe, zaščite in reševanja & 35 & 152,1 & 4,3 \\
\hline FDO pridobivanja mineralnih surovin & 170 & 649,9 & 3,8 \\
\hline FDO infrastrukture & 133 & 418,4 & 3,1 \\
\hline FDO prehodne rabe & 112 & 267,8 & 2,4 \\
\hline FDO za bivanje & 95 & 108,8 & 1,1 \\
\hline FDO skupaj & $\mathbf{1 0 8 1}$ & $\mathbf{3 4 2 2 , 7}$ & $\mathbf{3 , 2}$ \\
\hline
\end{tabular}


Slika 7: Število in površina funkcionalno degradiranih območij v Sloveniji po tipih.

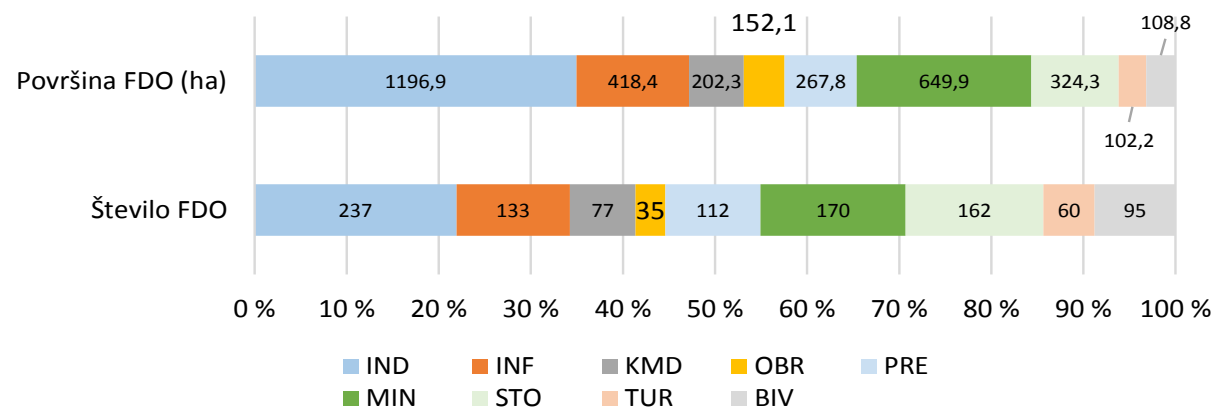

Opombe: IND - FDO industrijskih in obrtnih dejavnosti; INF - FDO infrastrukture; KMD - FDO kmetijske dejavnosti; OBR - FDO obrambe, zaščite in reševanja; PRE - FDO prehodne rabe; MIN - FDO pridobivanja mineralnih surovin; STO - FDO storitvenih dejavnosti; TUR - FDO turistične, športnorekreacijske in športne dejavnosti; BIV - FDO za bivanje.

Prostorska razporeditev FDO pokaže dejansko razsežnost pojava funkcionalno razvrednotenega prostora v Sloveniji (slika 8). Če smo še pred časom degradiran prostor povezovali predvsem z izrazito urbaniziranimi območji, današnja slika zastopanosti FDO praktično povsod po državi opozarja, da je ta pojav pomemben prostorski element tudi v podeželskem prostoru.

Slika 8: Prostorska razporeditev in velikost vseh evidentiranih funkcionalno degradiranih območij.

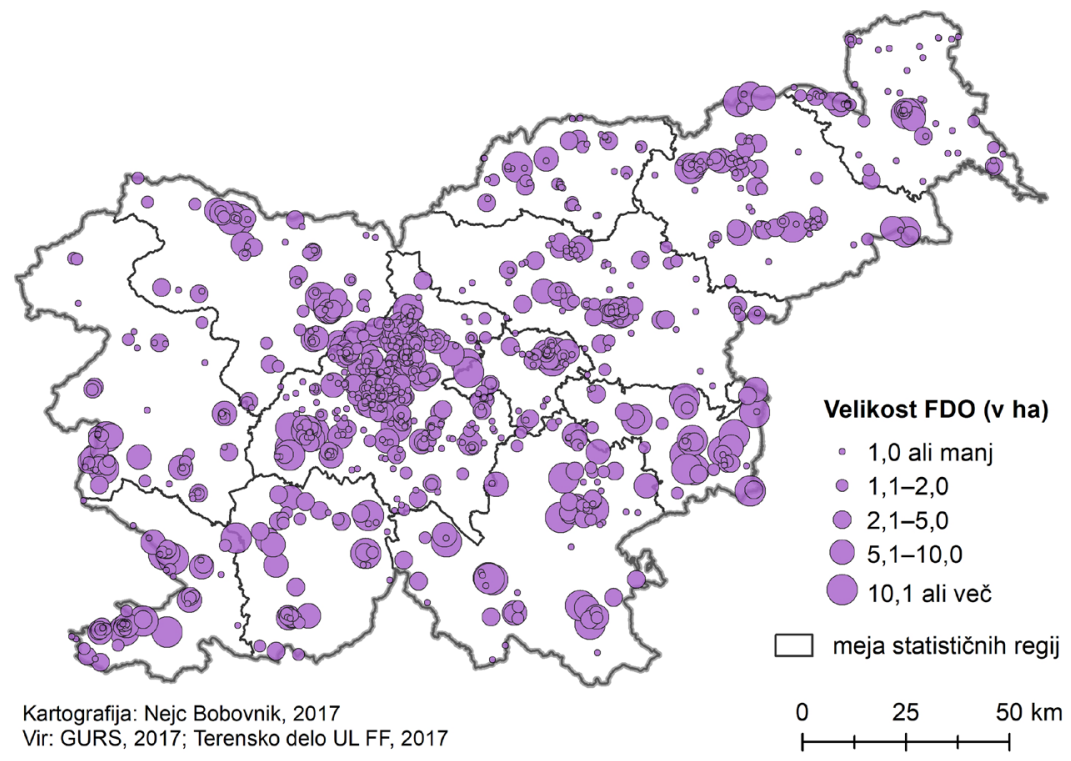


Čeprav so FDO prisotna na območju celotne Slovenije, je njihova zgostitev pričakovano izrazitejša v Osrednjeslovenski regiji, regionalno pa je večja koncentracija FDO še na širšem območju Celja, Maribora, Jesenic in v vzhodnem delu Posavske regije.

Analiza FDO po regijah nakazuje regionalne razvojne specifike dejavnosti, ki se odražajo v zastopanosti FDO v posameznih statističnih regijah. Njihovo največje število je bilo zabeleženo v Osrednjeslovenski statistični regiji (384), najmanjše pa v Posavski (40). Po največjih skupnih površinah FDO odstopajo Osrednjeslovenska regija (1103,2 ha), regija Jugovzhodna Slovenija (500,6 ha) in Posavska regija (350,8 ha) (slika 9).

Opuščenost dejavnosti predstavlja osnovni kriterij za opredelitev FDO, med območji pa prihaja do velikih razlik v stopnji opuščenosti zemljišč (in objektov). Podatki kažejo, da je največ (535 od skupaj 1081) povsem opuščenih območij, sledijo pa jim pretežno opuščena (347) in delno opuščena območja (192). Sedem območij je opredeljenih kot neopuščenih - sodijo v tip FDO za bivanje, kamor uvrščamo stara, izrazito dotrajana stanovanjska območja z vidnimi znaki fizične degradacije, pogosto tudi neurejenimi skupnimi funkcionalnimi zemljišči. Če je povsem opuščenih skoraj polovica vseh FDO v Sloveniji, je njihova skupna površina nekoliko manjša. Tako je povsem opuščenih zemljišč 1149 ha oziroma dobra tretjina (slika 9).

Slika 9: Funkcionalno degradirana območja glede na površino in stopnjo opuščenosti po statističnih regijah.

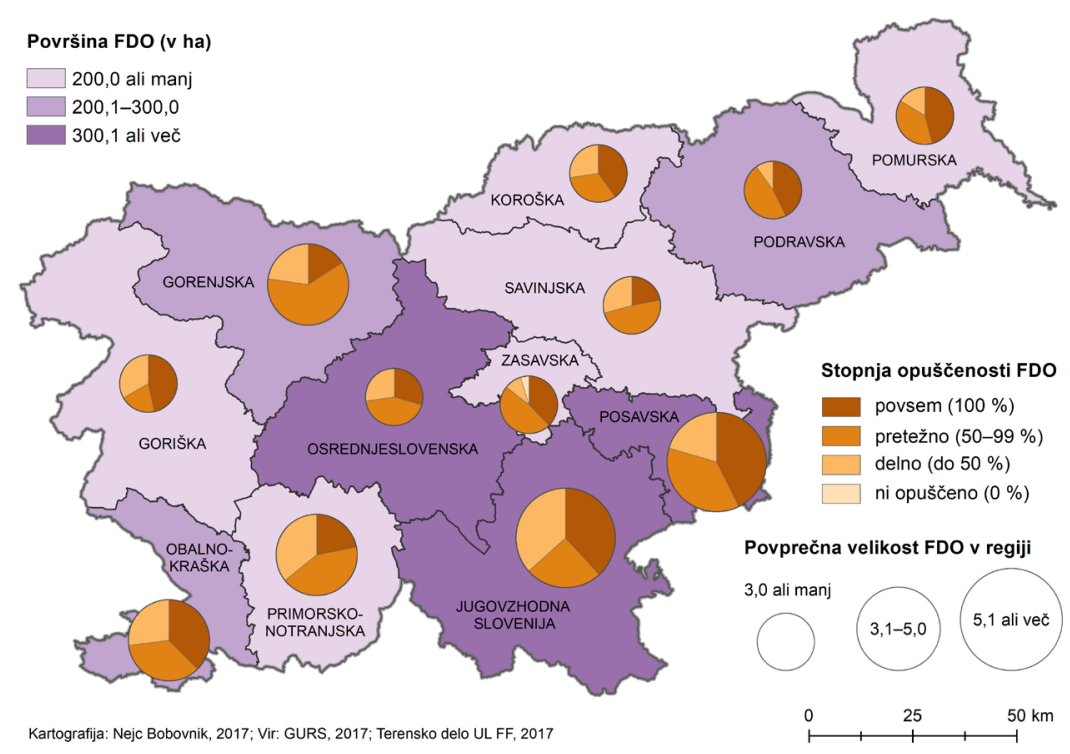

Regionalen prikaz strukture FDO glede na površine po stopnji opuščenosti kaže, da je največji delež povsem opuščenih površin FDO v Goriški, Pomurski, Podravski, Koroški regiji in regiji Jugovzhodna Slovenija, absolutno gledano pa povsem opuščene 
površine prevladujejo v Osrednjeslovenski regiji (323 ha), regiji Jugovzhodna Slovenija (191 ha) in Posavski regiji (150 ha). Omeniti velja še regionalne razlike v povprečni velikosti FDO, kjer so v povprečju največja v Posavski regiji $(8,8$ ha) in regiji Jugovzhodna Slovenija (6,6 ha), najmanjša pa v Koroški (1,3 ha) in Pomurski (1,5 ha) regiji. Precejšnje razlike gre do določene mere pripisati strukturi FDO, saj v regijah s povprečno večjimi območji prevladujejo industrijska oziroma infrastrukturna FDO, pri regijah s prevladujočimi manjšimi FDO pa so nadpovprečno zastopana FDO storitvenih dejavnosti.

Velikost evidentiranih območij (preglednica 5) je pomembna predvsem z vidika umeščanja novih razvojnih projektov v prostor. Večje investicijske pobude novih proizvodnih in drugih dejavnosti praviloma iščejo večja zaokrožena območja. Popis FDO je pokazal, da je zares velikih, homogenih razpoložljivih območij FDO v Sloveniji razmeroma malo. Območij, večjih od 30 ha, smo evidentirali le 16 (največ FDO industrijskih in obrtnih dejavnosti), vseh območij, večjih od 10 ha, pa 65. Skoraj polovica FDO (504 oziroma 46,6 \%) je manjših od 1 ha. Obstoječa kapaciteta FDO torej ne omogoča umeščanja velikopoteznih investicij, vendar je z razvojem tehnologije in preusmeritvijo gospodarstva $\mathrm{v}$ razvojno in inovacijsko intenzivne dejavnosti, kreativne dejavnosti ter z naraščajočo vlogo majhnih in srednje velikih podjetij v gospodarski strukturi njihovo umeščanje možno tudi v manjše gospodarske cone znotraj obstoječe poselitvene strukture.

Preglednica 5: Funkcionalno degradirana območja po posameznih velikostnih razredih in tipih.

\begin{tabular}{|l|r|r|r|r|r|c|}
\hline Tip FDO & $\begin{array}{c}\text { Manj kot 1 } \\
\text { ha }\end{array}$ & \multicolumn{1}{|c|}{$\begin{array}{c}\mathbf{1 - 2} \\
\text { ha }\end{array}$} & $\begin{array}{c}\mathbf{2}-\mathbf{5} \\
\text { ha }\end{array}$ & $\begin{array}{c}\mathbf{5}-\mathbf{1 0} \\
\text { ha }\end{array}$ & $\begin{array}{c}\mathbf{1 0 - 3 0} \\
\text { ha }\end{array}$ & $\begin{array}{c}\text { Več kot 30 } \\
\text { ha }\end{array}$ \\
\hline FDO kmetijske dejavnosti & 31 & 20 & 14 & 8 & 4 & 0 \\
\hline FDO storitvenih dejavnosti & 109 & 27 & 18 & 3 & 2 & 3 \\
\hline $\begin{array}{l}\text { FDO turistične, športnorekreacijske in } \\
\text { športne dejavnosti }\end{array}$ & 39 & 7 & 12 & 1 & 1 & 0 \\
\hline FDO industrijskih in obrtnih dejavnosti & 77 & 48 & 62 & 22 & 20 & 8 \\
\hline FDO obrambe, zaščite in reševanja & 9 & 10 & 9 & 3 & 3 & 1 \\
\hline FDO pridobivanja mineralnih surovin & 67 & 38 & 26 & 23 & 13 & 3 \\
\hline FDO infrastrukture & 57 & 35 & 23 & 15 & 2 & 1 \\
\hline FDO prehodne rabe & 53 & 22 & 25 & 9 & 3 & 0 \\
\hline FDO za bivanje & 62 & 18 & 14 & 0 & 1 & 0 \\
\hline FDO skupaj & $\mathbf{5 0 4}$ & $\mathbf{2 2 5}$ & $\mathbf{2 0 3}$ & $\mathbf{8 4}$ & $\mathbf{4 9}$ & $\mathbf{1 6}$ \\
\hline
\end{tabular}

Analiza razmer na najnižji prostorski ravni, po občinah, pokaže še bolj zanimivo prostorsko sliko. FDO so bila evidentirana v 170 občinah Slovenije. Tudi v številnih preostalih manjših občinah je bil zaznan pojav nefunkcionalnega, razvrednotenega prostora (na primer opuščene podružnične šole s pripadajočimi funkcionalnimi zemljišči, opuščena območja drugih storitvenih dejavnosti), ki pa jih zaradi njihove velikosti (manjša od 0,5 ha) nismo vključili v evidenco. V 8 občinah (Ljubljana, Domžale, Kamnik, Vrhnika, Celje, Medvode, Novo mesto, Ivančna Gorica) smo evidentirali več kot 20 FDO, v 35 občinah pa 10 ali več FDO. 17 občin ima po površini skupaj več kot 50 ha FDO, kar 44 občin 
pa več kot 30 ha FDO. Po zares veliki skupni površini FDO (več kot 100 ha) izstopajo občine Ljubljana (276,4 ha), Kočevje (185,5 ha), Brežice (168,8 ha), Krško (145,7 ha), Črnomelj (121,2 ha), Kamnik (119 ha) in Vrhnika (105 ha). V kar 95 slovenskih občinah je skupna površina FDO manjša od 10 ha, med njimi prevladujejo manjše občine v severovzhodni Sloveniji (slika 10).

Slika 10: Skupna površina FDO (v ha) po občinah Slovenije.

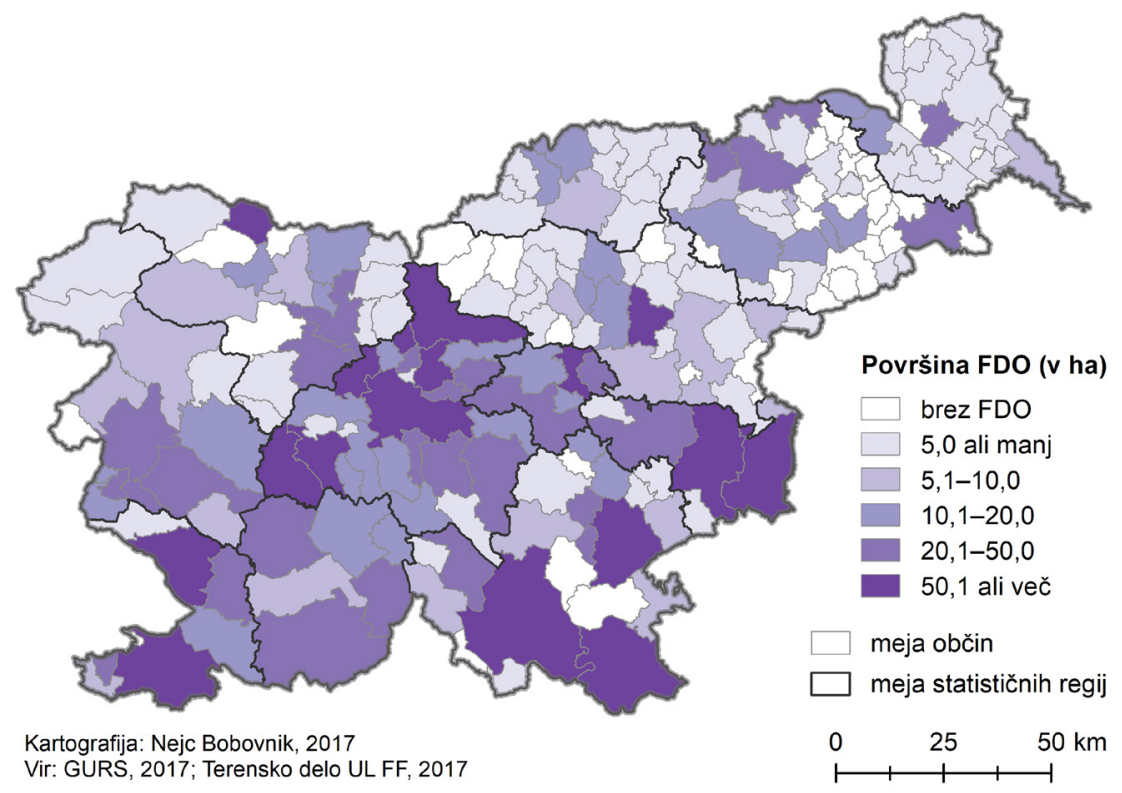

V postopku evidentiranja FDO smo v razgovoru z odgovornimi predstavniki za prostor na občinah preverjali tudi načrte za sanacijo oziroma oživitev posameznih FDO s strani občin, lastnikov oziroma potencialnih investitorjev. Odgovori so bili podani opisno, sogovorniki pa so jih razvrstili tudi glede na (ocenjeno) časovno razsežnost obnove (slika 11).

Na ravni celotne države je le za 15 \% vseh FDO že sprejet razvojni načrt - najpogosteje so občine poudarile, da je za območje že pripravljen občinski podrobni prostorski načrt (OPPN), včasih tudi, da je že izdano gradbeno dovoljenje za novo investicijo/gradnjo, da sta investitor in projekt znana ipd. Za večino FDO (44 \%) v Sloveniji ni nobenih načrtov, možnosti razvoja oziroma ni nobenih podatkov o razvojnih načrtih. Pogosto načrtovalci rabe v prostoru niso seznanjeni z morebitnimi načrti (poudarjajo moč lastnikov) oziroma nimajo možnosti vplivati na načrtovanje sanacije in reaktivacije.

Skoraj za tretjino FDO so občine izpostavile, da sicer že obstajajo konkretni načrti in ideje (tako s strani občine ali s strani lastnikov), da pa način in čas njihove realizacije nista znana. Zelo pogosto so navedli primere, ko je bila rešitev že predlagana, celo finančno podprta, potem pa je tik pred ali med samo izvedbo prišlo do spremembe ali težav. 
Slika 11: Predvideni načrti sanacije, oživitve območja (s strani občine).

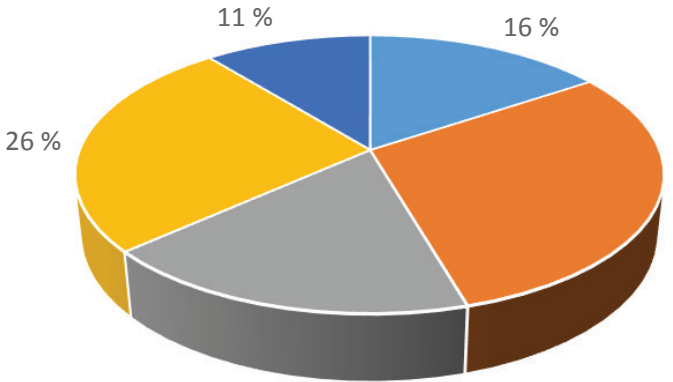

$18 \%$
- imamo že sprejet načrt za območje

- imamo načrte, ideje, realizacija pa še I definirana

" nimamo pravih oprijemljivih načrtov, zgolj pobude

- nimamo nobenih načrtov, ni nobenih možnosti sprememb, razvoja

- ni podatka

Prikaz časovnega okvira načrtovane reaktivacije opozarja, da na načelni ravni za številna območja obstajajo že sprejeti načrti oziroma vsaj realni načrti za izvedbo (45 \% FDO, slika 11), ko pa smo vprašali o predvidenem času realizacije teh načrtov in pobud, se je pokazalo, da je zgolj za $21 \%$ območij realizacija načrtovana v naslednjih petih letih, medtem ko za 67 \% vseh evidentiranih FDO občine nimajo predvidenih časovnih okvirov za njihovo sanacijo oziroma reaktivacijo oziroma ne razpolagajo s tem podatkom (slika 12).

Slika 12: Časovni okviri načrtovane oživitve območja (ocena občine).

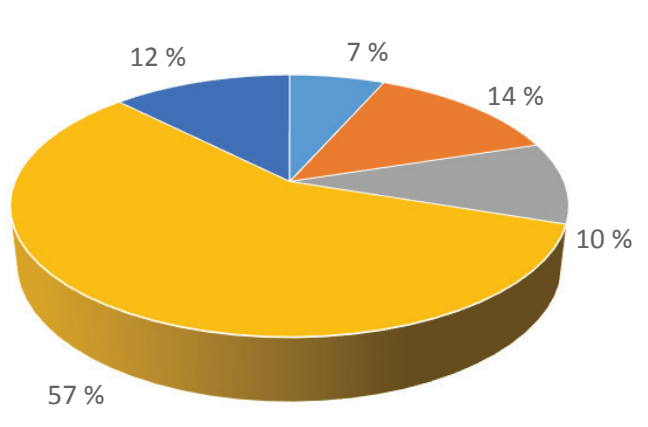

\author{
- v času do 2 leti \\ - v času 2-5 let \\ v času 5-10 let \\ ine ne ve, \\ neopredeljeno \\ - ni podatka
}

Pregled razvojnih načrtov po tipih FDO kaže, da je največ sprejetih načrtov za območja prehodne rabe (območja opuščenih gradbišč) in FDO za bivanje, najbolj negotova pa se kaže rešitev za FDO kmetijske dejavnosti in FDO infrastrukture. 
Slika 13: Predvideni načrti oživitve po tipih FDO.

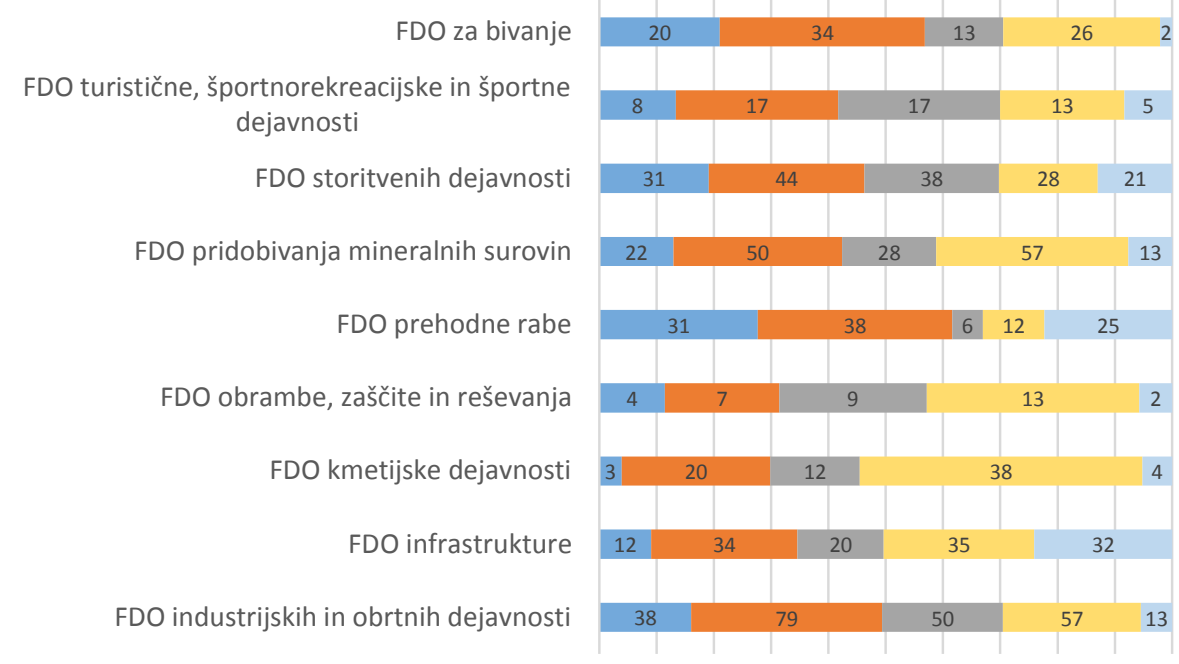

$0 \% 10 \% 20 \% 30 \% 40 \% 50 \% 60 \% 70 \% 80 \% 90 \% 100 \%$

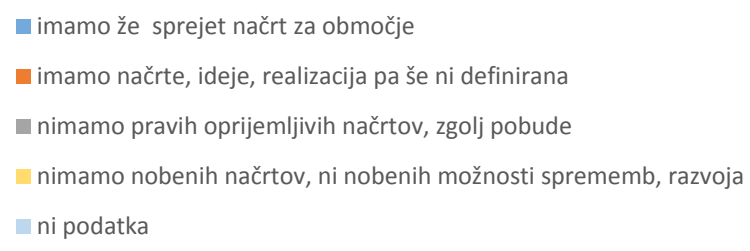

Skupni rezultati za vse obravnavane statistične regije kažejo, da imajo številne regije kohezijske regije Vzhodna Slovenija (Podravska, Pomurska in Posavska statistična regija) več težav z načrtovanjem reaktivacije degradiranih območij kot tiste iz kohezijske regije Zahodna Slovenija (velja predvsem za Gorenjsko in Goriško statistično regijo). V kohezijski regiji Vzhodna Slovenija izkazujeta statistična regija Jugovzhodna Slovenija in Savinjska statistična regija več aktivnosti na področju oživitve degradiranih območij, kar je razvidno iz slike 14.

Iz analize velikosti, tipov, stopnje opuščenosti in drugih podatkov o popisanih FDO se vsaj deloma zrcalijo tudi strukturni problemi, ki so prisotni v obravnavanih statističnih regijah: veliko število FDO industrijskih in obrtnih dejavnosti je vsekakor kazalnik, ki kaže na veliko stopnjo sprememb v gospodarski strukturi (oziroma vsaj korelira z njo). S tem je na nekaterih območjih zagotovo povezano tudi opuščanje storitvenih dejavnosti. Manj zastopane so FDO turistične, športnorekreacijske in športne dejavnosti, ki se v večjem številu (12) pojavljajo le na območju Gorenjske statistične regije. Najmanj je FDO za bivanje, ki pa zaradi drugih kriterijev, ki v tem popisu niso bili zajeti, ne izkazujejo pravega stanja na terenu. 
Slika 14: Predvideni načrti revitalizacije funkcionalno degradiranih območij na ravni posameznih statističnih regij.

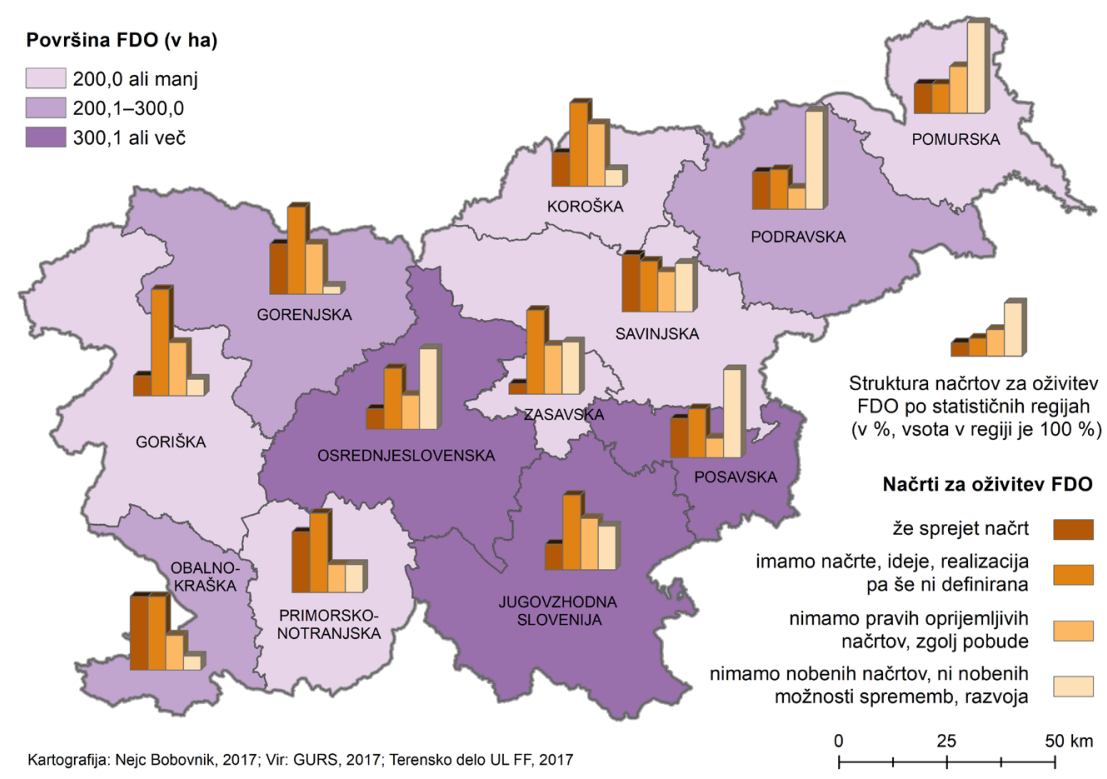

\section{RAZPRAVA IN SKLEPI}

Že uvodoma smo zapisali, da pojav FDO v Sloveniji zaznamuje velika dinamika, ki je rezultat številnih dejavnikov in družbenih procesov: zaradi opuščanja dejavnosti ali njihovih spremenjenih (prostorskih) potreb nastajajo vedno nova FDO. Hkrati se v obstoječih FDO umeščajo nove dejavnosti in tako prihaja do njihove delne, postopne ali pa celovite oživitve. Glede na veliko število evidentiranih FDO v Sloveniji v letih 2016 in 2017 (skupaj 1081 FDO), njihovo skupno površino (3422,7 ha) ter njihove značilnosti (velikost, stopnja opuščenosti, lastniška heterogenost, infrastrukturna opremljenost, prisotnost različnih oblik degradacije ipd.) je nujno potrebna hitra odzivnost in sistemsko ukrepanje različnih resorjev državne ravni pa tudi regionalne in lokalne ravni, kar bo zagotovilo usmerjeno in sistematično reševanje njihove problematike.

V predstavljeni raziskavi pa tudi nekaterih predhodnih študijah (na primer CABERNET, 2006; Environmental liability ..., 2011) se je potrdilo, da je zaradi boljšega razumevanja, lažje obvladljivosti problematike degradiranih območij in bolj usmerjenih predlogov za njihovo oživitev smiselno njihovo obravnavo usmeriti na posamezne vrste degradiranosti (fizična, vizualna, okoljska, funkcionalna, socialna, neskladnost rabe z veljavnimi prostorskimi akti itd.). V okviru predlaganega pristopa obravnave FDO smo se zato načrtno osredotočili na prostor, kjer se človekova dejavnost ne izvaja oziroma se izvaja v omejenem obsegu, pri tem pa v modelu za celovito obravnavo FDO pustili dovolj 
prostora tudi za vključitev ostalih oblik (na primer socialna, okoljska) in tipov (na primer kmetijska) degradacije, ki jih bo mogoče vključiti v zasnovano evidenco degradiranih območij. Ocenjujemo, da bo v prihodnje dopolnjena predvsem podrobnejša tipologija (podtipi) trenutnih devetih predvidenih glavnih tipov FDO.

Cilj vzpostavljene nacionalne evidence, ki omogoča vpogled $\mathrm{v}$ aktualno stanje na področju funkcionalno razvrednotenih območij, je prednostno vezan na njihovo ponovno oživitev oziroma razvojno aktiviranje.

Ugotavljamo, da je še posebej zahtevno ustrezno umeščanje dejavnosti (po vrsti in obsegu) na tista območja, ki so deloma že (še) v funkciji, kar smo marsikje zaznali tudi na terenu samem. V praksi je vse prevečkrat prodaja še praznih zemljišč znotraj nekdaj zaokroženega funkcionalnega območja prepuščena stihiji, kar na koncu pripelje do lastniške drobitve območja in razpada večje homogene celote. S tem je onemogočeno načrtovanje dejavnosti za večjega investitorja. Drobljenje funkcionalno zaokroženih FDO zato onemogoča celovit pristop k urejanju in aktivaciji območja (na primer z OPPN), zato pogosto prihaja le do delne oživitve, ki pa se v prostoru kaže kot neurejeno stanje oziroma fizična (vizualna) degradacija prostora.

Izkušnje iz terenskega dela kažejo, da so možnosti za oživitev posameznega FDO odvisne predvsem od lastniške strukture (vrsta, število in heterogenost lastništva), finančnih kapacitet lastnika, lokacije, sprejetih (občinskih) aktov ipd.

Vzroke za (ne)uspešno oživitev FDO je najpogosteje treba iskati v:

- Zahtevnem finančnem vložku kot enem glavnih vzrokov, ki zavirajo sanacijo in ponovno oživitev FDO. Omejenost finančnih sredstev lastniki FDO in/ali občine skušajo reševati s prijavami na različne domače in mednarodne razpise ali pa z iskanjem ustreznih investitorjev, ki bi bili pripravljeni vlagati v sanacijo FDO.

- Lastniški strukturi FDO, ki se pogosto kaže v obliki nerešenega ali neznanega lastništva, večjega števila solastnikov z različnimi interesi, mešanega javno-zasebnega lastništva, nezainteresiranih lastnikov, katerih cilj je le prodaja FDO za zelo visoko ceno, dolgotrajnih postopkov prenosa lastništva z države na občino, dolgotrajnosti stečajnih postopkov podjetij, ki so lastniki FDO ipd.

- Prostorskih aktih občin in države kot pogosto prepoznanih razlogih za zmanjšane možnosti prenove FDO, saj se lastniki oziroma investitorji srečujejo z neskladjem glede namenske rabe prostora. V sprejetih prostorskih aktih občin veljavna namenska raba prostora namreč pogosto ne ustreza več dejanskim razmeram, predvsem pa razvojnim potrebam v prostoru. Postopki sprejemanja ustreznih občinskih prostorskih načrtov ali občinskih podrobnih prostorskih načrtov bistveno vplivajo na časovni okvir procesa prenove FDO.

- Pomanjkljivi gospodarski javni infrastrukturi kot zaviralcu oživitve in razvoja, saj potencialni investitorji ne želijo vlagati v FDO, ki nimajo ustrezno urejenih dostopov, so slabo prometno urejena ali pa še nimajo urejene gospodarske javne infrastrukture.

- (Pre)pogostem spreminjanju zakonodaje na različnih področjih, kadar se FDO nahaja na območjih javno-pravnih varstvenih režimov (vodovarstveno območje, Natura 2000, zavarovano območje, območje kulturne dediščine idr.). Dolgi so tudi postopki pridobivanja okoljevarstvenih dovoljenj. 
Od oktobra 2017 v Sloveniji razpolagamo z novim prostorskim in podatkovnim slojem o funkcionalno degradiranem prostoru, podatki pa so zbrani in urejeni v obliki, ki omogoča tako vpogled preko javno dostopne aplikacije (povezava: http://crp.gis. si/) kot tudi prenos evidentiranih podatkov, poligonov območij in fotografij $\mathrm{v}$ druga programska okolja.

Ta evidenca je omogočila razkrivanje vrst, količine (števila, površine) in vzrokov za nastanek FDO v Sloveniji. Njena zasnova temelji na geografskem, prostorskonačrtovalskem in upravljavskem razumevanju prostora. S svojo široko zasnovo, ki omogoča dodajanje novih vrst in tipov degradiranih območij, je v Sloveniji prvič omogočeno ažurno kvantitativno spremljanje pojava degradiranih območij. Opozoriti je treba, da bo evidenca dosegla svoj namen le z vzpostavitvijo sistema za njeno (letno) ažuriranje na državni ravni, $\mathrm{k}$ čemur je treba pristopiti z medsektorsko usklajenim načinom delovanja. Uporabno vrednost evidence bi izboljšal tudi hkratni dostop do podatkov o relevantnih lokacijskih dejavnikih za različne dejavnosti (industrija, storitve, stanovanja ...), predvsem celovitih podatkov o prometni, okoljski in ostali gospodarski infrastrukturi (glej na primer Jurinčič, 1993; Jeršič, 1999).

Ker se soočamo s hitrimi spremembami, ki se pogosto izražajo kot nepredvidene možnosti in potrebe investitorjev po površinah za načrtovanje (predvsem) gospodarskih dejavnosti, so ažurni podatki o stanju in procesih v prostoru ter spremljanje hitrih sprememb še toliko bolj pomembni. Vedno manj je namreč delujočih mehanizmov za spremljanje, usmerjanje in nadzor sprememb v prostoru, kar v praksi še zmanjšuje zmožnosti pravočasnega odzivanja relevantnih resorjev in strok. Nujna pa je tudi določitev ustreznega skrbnika, ki vodi prostorsko politiko, saj nenazadnje to vpliva, da evidenca srednjeročno oziroma dolgoročno preraste $\mathrm{v}$ register.

$\mathrm{S}$ promocijo, javnim dostopom in vpogledom $\mathrm{v}$ dejansko stanje $\mathrm{v}$ prostoru ter ustreznim metodološko-tehničnim razvojem tega novega prostorskega sloja lahko bistveno pripomoremo k zmanjševanju območij netrajnostne rabe prostora v Sloveniji. Istočasno smo z novo vzpostavljeno evidenco FDO pridobili odlično podlago, da se lahko v Sloveniji končno sistematično in celovito lotimo priprave učinkovitih (zakonodajnih, prostorsko-planskih, finančnih in podpornih) ukrepov, ki bodo pripomogli k njihovi ponovni oživitvi.

Zahvala: Evidentiranje FDO v Sloveniji je bilo sofinancirano s strani ARRS in MGRT v okviru projekta CRP V6-1510 z naslovom Celovita metodologija za popis in analizo degradiranih območij, izvedba pilotnega popisa in vzpostavitev ažurnega registra (2015-2017) ter samostojne projektne naloge (2017), ki jo je financiralo MGRT.

\section{Viri in literatura}

Adams, D., De Sousa, C., Tiesdell, S., 2010. Brownfield development: A Comparison of North American and British approaches. Urban studies, 47, 19, str. 75-104. DOI: 10.1177/0042098009346868. 
Alker, S., Joy, V., Roberts, P., Smith, N., 2000. The definition of brownfield. Journal of environmental planning and management, 43, 1, str. 49-69. DOI: 10.1080/09640560010766.

Bergatt Jackson, J., Drobiec, L., Ferber, U., Gorski, M., Nathanail, P., Petríková, D., 2006. Brownfields handbook. URL: http://fast10.vsb.cz/lepob/index1/handbook_eng_screen.pdf (citirano 10. 1. 2016).

Brownfield Action. What is a ,"brownfield“"? URL: http://brownfieldaction.org/brownfieldaction/brownfield_basics (citirano 9. 12.2015).

CABERNET: Sustainable brownfield regeneration. Cabernet Network report. 2006. Nottingham, University of Nottingham, 134 str. URL: http:/www.palgo.org/files/ CABERNET\%20Network\%20Report\%202006.pdf (citirano 12. 2. 2017).

COBRAMAN Brownfield Types. URL: http://database.cobraman-ce.eu/BrownfieldTypes.php (citirano 7. 3. 2016).

COBRAMAN. COBRAMAN Manager Coordinating Brownfield Redevelopment Activities. 2009. URL: http://www.cobraman-ce.eu/ (citirano 28. 02. 2017).

Dasgupta, S., Tam, E. K. L., 2009. A comprehensive review of existing classification systems of brownfield sites. Environmental practice, 11, 4, str. 285-300. DOI: $10.1017 /$ S1466046609990287.

DIGISOIL. Integrated system of data collection technologies for mapping soil properties. 2011. URL: http://cordis.europa.eu/project/rcn/88390_en.html (citirano 13. 3. 2017).

Dolinšek, M., 2016. Degradirana območja v Zasavski regiji. Diplomsko delo. Ljubljana, Fakulteta za gradbeništvo in geodezijo, 63 str.

Encyclopedic Dictionary of Landscape and Urban Planning. Multilingual Reference Book in English, Spanish, French, and German. 2010. Evert, K. J. (ur.). Berlin, Heidelberg, Springer-Verlag, 1152 str.

Environmental liability transfer in Europe: Disvestment of contaminated land for brownfield regeneration. Report. 2011. URL: http://www.nicole.org/uploadedfiles/2011-wg-brownfields-finalreport.pdf (citirano 13. 12. 2017).

Ferber, U., Grimski, D., 2002. Brownfields and redevelopment of urban ares. URL: http://www.commonforum.eu/Documents/DOC/Clarinet/brownfields.pdf (citirano 21. 12. 2015).

Gauchon, M. C., 1997. Anciennes remontées mécaniques dans les montagnes françaises: pour une géographie des friches touristiques. Bulletin de 1'Association de géographes français, 74, 3, str. 296-310.

Grčman, H., 2017. Onesnaževanje tal. URL: http://www.mop.gov.si/fileadmin/mop.gov. si/pageuploads/podrocja/tla/srecanje_partnerstvo_tla_dec17_onesnazevanje.pdf (citirano 13. 12. 2017).

Hribernik, M., 2012. Vrednotenje degradiranih območij v občinah zahodne Savinjske regije. Diplomsko delo. Velenje, Visoka šola za varstvo okolja, 62 str.

Jeršič, M., 1999. Prostorsko planiranje rekreacije na prostem. Ljubljana, Ministrstvo za okolje in prostor, 135 str.

Jurinčič, I., 1993. Regionalno vrednotenje možnih lokacij za namestitev industrije (ob uporabi geografskega informacijskega sistema). Magistrsko delo. Ljubljana, Univerza v Ljubljani, Filozofska fakulteta, Oddelek za geografijo, 146 str. 
Klančišar Schneider, K., 2014. Problemska analiza prenove degradiranih industrijskih območij na primeru občine Trbovlje. Magistrsko delo. Ljubljana, Fakulteta za gradbeništvo in geodezijo, 169 str. URL: http://drugg.fgg.uni-lj.si/5178/1/Magd_Klancisar2014k.pdf (citirano 21. 12. 2015).

Koželj, J., 1998. Degradirana urbana območja. Ljubljana, Ministrstvo za okolje in prostor, Urad RS za prostorsko planiranje, 252 str.

Koželj, J., Filipič, P., Hočevar, P., Strle, K., Kušar, K., Lavtižar, K., Gracar, M., Cafuta, O., 2016. Merila in kriteriji za določitev degradiranih urbanih območij (DUO 2). Zaključno poročilo, faza 1 in 2. Ljubljana, Univerza v Ljubljani, Fakulteta za arhitekturo, $253 \mathrm{str}$.

Lampič, B., Marot, N., Gamse, M., Jenko, I., Kljun, U., Mali, K., Korošec, T., Verlič, L., Žabota, B., 2015. Vzpostavitev aktivnega registra prostorsko in funkcijsko degradiranih območij za Gorenjsko regijo: končno poročilo. Ljubljana, Oddelek za geografijo Filozofske fakultete, Oddelek za krajinsko arhitekturo Biotehniške fakultete, 120 str.

Lampič, B., Cigale, D., Kušar, S., Potočnik Slavič, I., Foški, M., Zavodnik Lamovšek, A., Barborič, B., Meža, S., Radovan D., 2016. Celovita metodologija za popis in analizo degradiranih območij, izvedba pilotnega popisa in vzpostavitev ažurnega registra. 1. vmesno poročilo projekta CRP V6-1510. Ljubljana, Filozofska fakulteta Univerze v Ljubljani, Fakulteta za gradbeništvo in geodezijo Univerze v Ljubljani, Geodetski inštitut Slovenije, 51 str.

Lampič, B., Cigale, D., Kušar, S., Potočnik Slavič, I., Foški, M., Zavodnik Lamovšek, A., Barborič, B., Meža, S., Radovan D., 2017a. Celovita metodologija za popis in analizo degradiranih območij, izvedba pilotnega popisa in vzpostavitev ažurnega registra. Končno poročilo. Ljubljana, Filozofska fakulteta Univerze v Ljubljani, Fakulteta za gradbeništvo in geodezijo Univerze v Ljubljani, Geodetski inštitut Slovenije, 192 str.

Lampič, B., Foški, M., Zavodnik Lamovšek, A., Barborič, B., Cigale, D., Kušar, S., Mrak, G., Potočnik Slavič, I., Radovan D., 2017b. Evidentiranje in analiza funkcionalno degradiranih območij v izbranih statističnih regijah Slovenije. Urbani izziv, 7, str. 10-18.

Landscapes2, Bringing growth and preservation together for Chester County. Redevelopment/Adaptive reuse of brownfield and greyfield sites. URL: http://www.landscapes2. org/ToolsLandscape/Pages/redevelopment.cfm (citirano 22. 12. 2015).

Lange, D., McNeil, S., 2004. Clean it and they will come? Defining successful brownfield development. Journal of urban planning and development, 130, str. 101-108.

Lipovac, N., 2014. Englesko-hrvatski stručni pojmovnik za urbaniste, prostorne planere, arhitekte i krajobrazne arhitekte. Zagreb, Sveučilište u Zagrebu, Arhitektonski fakultet, $250 \mathrm{str}$.

Mestna naselja v Republiki Sloveniji, 2003. 2004. Ljubljana, Statistični urad Republike Slovenije, 140 str.

NLUD-PDL: National land use database of previously developed land. Homes \& Communities Agency. 2004. URL: https://www.gov.uk/government/collections/national-land-use-database-of-previously-developed-land-nlud-pdl (citirano 20. 11. 2016).

Politika urejanja prostora. 2001. Ljubljana, Ministrstvo za okolje, prostor in energijo, 14 str. 
Pravilnik o vsebini, obliki in načinu priprave občinskega prostorskega načrta ter pogojih za določitev območij sanacij razpršene gradnje in območij za razvoj in širitev naselij. URL: http://www.pisrs.si/Pis.web/pregledPredpisa?id=PRAV8105 (citirano 13. 12. 2017).

RESCUE: Regeneration of european sites in cities and urban environments. Management of the brownfield regeneration projects. 2002. URL: http://www.rescueproject.eu/index.html (citirano 28. 2. 2017).

RETINA. BRM Brownfield Revitalisation Methodology. 2012. Maribor, University of Maribor, Faculty of Arts, 90 str. URL: www.southeast-europe.net/document.cmt? id=457 (citirano 21. 12. 2015).

Science for Environment Policy. No net land take by 2050? Future Brief 14. 2016. Bristol, European Commission DG Environment by the Science Communication Unit. URL: http://ec.europa.eu/science-environment-policy (citirano 19. 5. 2017).

Strategija prostorskega razvoja Slovenije. 2004. Ljubljana, Ministrstvo za okolje, prostor in energijo, 75 str.

Špes, M., Krevs, M., Lampič, B., Mrak, I., Ogrin, M., Plut, D., Vintar Mally, K., Vovk Korže, A., 2012. Sonaravna sanacija okoljskih bremen kot trajnostno razvojna priložnost Slovenije, Degradirana območja: zaključno poročilo. Ljubljana, Univerza v Ljubljani, Filozofska fakulteta, Oddelek za geografijo, 66 str.

TIMBRE: Tailored improvement of brownfield regeneration in Europe. 2011. URL: http://www.timbre-project.eu/ (citirano 12. 2. 2017).

Udovič, H., 2017. Vključevanje prebivalcev v reaktivacijo degradiranega območja rudnika Trbovlje-Hrastnik. Zaključna seminarska naloga. Ljubljana, Univerza v Ljubljani, Oddelek za geografijo Filozofske fakultete, 38 str.

Vojvodíková, B., Potužník, M., Bürgermeisterová, R., 2011. The database on brownfields in Ostrava (Czech Republic): some approaches to categorization. Moravian geographical reports, 19, 4, str. 50-60.

Zakon o varstvu okolja. 2004. Uradni list RS, 41, str. 4818-4853.

Zakon o urejanju prostora. 2017. Uradni list RS, 61, str. 8255-8310.

Zupan, D., 2016. Analiza in vrednotenje degradiranih urbanih območij na izbranem primeru. Diplomsko delo. Ljubljana, Fakulteta za gradbeništvo in geodezijo, 41 str. 